\title{
SARS-CoV-2 reinfection in a cohort of 43,000 antibody- positive individuals followed for up to 35 weeks
}

Laith J. Abu-Raddad, $\mathrm{PhD}^{1,2,3^{*}}$, Hiam Chemaitelly, $\mathrm{MSc}^{1,2}$, Peter Coyle, MD ${ }^{4}$, Joel A. Malek, $\mathrm{PhD}^{5,6}$, Ayeda A. Ahmed, BSc ${ }^{5}$, Yasmin A. Mohamoud, MSc ${ }^{5}$, Shameem Younuskunju, MSc ${ }^{5}$, Houssein H. Ayoub, $\mathrm{PhD}^{7}$, Zaina Al Kanaani, $\mathrm{PhD}^{4}$, Einas Al Kuwari, $\mathrm{MD}^{4}$, Adeel A. Butt, MBBS MS ${ }^{3,4}$, Andrew Jeremijenko, $\mathrm{MD}^{4}$, Anvar Hassan Kaleeckal, $\mathrm{MSc}^{4}$, Ali Nizar Latif, $\mathrm{MD}^{4}$, Riyazuddin Mohammad Shaik, MSc${ }^{4}$, Hanan F. Abdul Rahim, $\mathrm{PhD}^{8}$, Gheyath K. Nasrallah, $\mathrm{PhD}^{9,10}$, Hadi M. Yassine, PhD ${ }^{9,10}$, Mohamed G. Al Kuwari, MD ${ }^{11}$, Hamad Eid Al Romaihi, $\mathrm{MD}^{12}$, Mohamed H. Al-Thani, MD ${ }^{12}$, Abdullatif Al Khal, MD ${ }^{4}$, and Roberto Bertollini, MD ${ }^{12}$

${ }^{1}$ Infectious Disease Epidemiology Group, Weill Cornell Medicine-Qatar, Cornell University, Doha, Qatar

${ }^{2}$ World Health Organization Collaborating Centre for Disease Epidemiology Analytics on HIV/AIDS, Sexually Transmitted Infections, and Viral Hepatitis, Weill Cornell Medicine-Qatar, Cornell University, Qatar Foundation - Education City, Doha, Qatar

${ }^{3}$ Department of Population Health Sciences, Weill Cornell Medicine, Cornell University, New York, New York, USA

${ }^{4}$ Hamad Medical Corporation, Doha, Qatar

${ }^{5}$ Genomics Laboratory, Weill Cornell Medicine-Qatar, Cornell University, Doha, Qatar

${ }^{6}$ Department of Genetic Medicine, Weill Cornell Medicine-Qatar, Cornell University, Doha, Qatar

${ }^{7}$ Department of Mathematics, Statistics, and Physics, Qatar University, Doha, Qatar

${ }^{8}$ College of Health Sciences, QU Health, Qatar University, Doha, Qatar

${ }^{9}$ Biomedical Research Center, Member of QU Health, Qatar University, Doha, Qatar

${ }^{10}$ Department of Biomedical Science, College of Health Sciences, Member of QU Health, Qatar University, Doha, Qatar

${ }^{11}$ Primary Health Care Corporation, Doha, Qatar

${ }^{12}$ Ministry of Public Health, Doha, Qatar

Word count: Abstract: 341 words, Main Text: 3,478 words.

Number of figures: 4 . Number of tables: 2; Number of boxes: 1 .

Running head: Reinfection with SARS-CoV-2.

Keywords: SARS-CoV-2; epidemiology; reinfection; immunity; genetics.

*Address reprints requests or correspondence to Professor Laith J. Abu-Raddad, Infectious Disease Epidemiology Group, World Health Organization Collaborating Centre for Disease Epidemiology Analytics on HIV/AIDS, Sexually Transmitted Infections, and Viral Hepatitis, Weill Cornell Medicine - Qatar, Qatar Foundation - Education City, P.O. Box 24144, Doha, Qatar. Telephone: +(974) 4492-8321. Fax: +(974) 4492-8333. E-mail: 1ja2002@ qatarmed.cornell.edu. 
medRxiv preprint doi: https://doi.org/10.1101/2021.01.15.21249731; this version posted February 8, 2021. The copyright holder for this preprint (which was not certified by peer review) is the author/funder, who has granted medRxiv a license to display the preprint in perpetuity.

All rights reserved. No reuse allowed without permission.

\begin{abstract}
Background: Reinfection with the severe acute respiratory syndrome coronavirus 2 (SARSCoV-2) has been documented, raising public health concerns. Risk and incidence rate of SARSCoV-2 reinfection were assessed in a large cohort of antibody-positive persons in Qatar.

Methods: All SARS-CoV-2 antibody-positive persons with a PCR-positive swab $\geq 14$ days after the first-positive antibody test were individually investigated for evidence of reinfection. Viral genome sequencing was conducted for paired viral specimens to confirm reinfection. Incidence of reinfection was compared to incidence of infection in the complement cohort of those antibody-negative.
\end{abstract}

Results: Among 43,044 anti-SARS-CoV-2 positive persons who were followed for a median of 16.3 weeks (range: $0-34.6), 314$ individuals (0.7\%) had at least one PCR positive swab $\geq 14$ days after the first-positive antibody test. Of these individuals, 129 (41.1\%) had supporting epidemiological evidence for reinfection. Reinfection was next investigated using viral genome sequencing. Applying the viral-genome-sequencing confirmation rate, the risk of reinfection was estimated at $0.10 \%(95 \% \mathrm{CI}: 0.08-0.11 \%)$. The incidence rate of reinfection was estimated at 0.66 per 10,000 person-weeks (95\% CI: 0.56-0.78). Incidence rate of reinfection versus month of follow-up did not show any evidence of waning of immunity for over seven months of followup. Meanwhile, in the complement cohort of 149,923 antibody-negative persons followed for a median of 17.0 weeks (range: 0-45.6), risk of infection was estimated at $2.15 \%$ (95\% CI: 2.08$2.22 \%$ ) and incidence rate of infection was estimated at 13.69 per 10,000 person-weeks (95\% CI: 13.22-14.14). Efficacy of natural infection against reinfection was estimated at $95.2 \%$ (95\% CI: 94.1-96.0\%). Reinfections were less severe than primary infections. Only one reinfection was 
medRxiv preprint doi: https://doi.org/10.1101/2021.01.15.21249731; this version posted February 8, 2021. The copyright holder for this preprint (which was not certified by peer review) is the author/funder, who has granted medRxiv a license to display the preprint in perpetuity. All rights reserved. No reuse allowed without permission.

severe, two were moderate, and none were critical or fatal. Most reinfections $(66.7 \%)$ were diagnosed incidentally through random or routine testing, or through contact tracing.

Conclusions: Reinfection is rare. Natural infection appears to elicit strong protection against reinfection with an efficacy $\sim 95 \%$ for at least seven months. 
medRxiv preprint doi: https://doi.org/10.1101/2021.01.15.21249731; this version posted February 8, 2021. The copyright holder for this preprint (which was not certified by peer review) is the author/funder, who has granted medRxiv a license to display the preprint in perpetuity.

All rights reserved. No reuse allowed without permission.

\section{INTRODUCTION}

The severe acute respiratory syndrome coronavirus 2 (SARS-CoV-2) pandemic has caused extensive disease and death, with heavy social and economic losses [1-4]. In addition to the risk of first infection, reinfection during this prolonged pandemic has raised additional public health concerns [5-9].

We recently assessed the risk and incidence rate of documented reinfection in a cohort of 130,266 SARS-CoV-2 polymerase chain reaction (PCR)-confirmed infected persons in Qatar [5], a country of 2.8 million population $[10,11]$ that experienced a large SARS-CoV-2 epidemic [1216]. Benefiting from a centralized data-capture system for nationwide SARS-CoV-2 PCR testing and using viral genome sequencing, we quantified the risk of reinfection at $\sim 2$ reinfections per 10,000 infected persons [5]. Incidence rate of reinfection was estimated at 0.36 (95\% CI: 0.280.47) per 10,000 person-weeks [5].

Serological testing for SARS-CoV-2 infection has been expanding in Qatar during the last few months $[14,16,17]$. The first objective of the present study was to quantify the risk and incidence rate of documented reinfection in a cohort of 43,044 persons who had a laboratoryconfirmed, anti-SARS-CoV-2 positive result, regardless of whether these persons had ever had a diagnosed PCR-confirmed infection. Persons with a PCR-confirmed infection could, in principle, be biologically different from persons with an antibody-confirmed infection, as the former population is more likely to have experienced symptomatic or even serious primary infection, while the latter population is more likely to have experienced an asymptomatic or mild primary infection that may never have been diagnosed. Moreover, some of those with PCR-confirmed infection may not have developed detectable antibodies $[5,7]$. The second objective was to estimate the efficacy of natural infection against reinfection by comparing incidence rate of 
medRxiv preprint doi: https://doi.org/10.1101/2021.01.15.21249731; this version posted February 8, 2021. The copyright holder for this preprint (which was not certified by peer review) is the author/funder, who has granted medRxiv a license to display the preprint in perpetuity.

All rights reserved. No reuse allowed without permission.

reinfection to incidence rate of infection in the complement cohort of 149,923 persons who had a laboratory-confirmed, anti-SARS-CoV-2 negative result.

The present study thus provides an independent assessment of the risk of reinfection in a biologically different population from that of PCR-confirmed infected persons. A major strength of the present study is the long follow-up time of each antibody-positive person in this cohort, which had a median of 16.3 weeks for a total cohort follow-up time of 610,832.6 person-weeks, comparable to or greater than the follow-up time in COVID-19 vaccine trials [18-20]. An added strength is the comparison to incidence rate of infection in a large cohort of antibody-negative persons with a similar follow-up time. The study therefore allows assessment of reinfection for more than seven months after primary infection, and provides empirical evidence for possible effects of any waning of immunity.

\section{METHODS}

\section{Sources of data}

We analyzed the centralized and standardized national anti-SARS-CoV-2 serological testing database compiled at Hamad Medical Corporation (HMC), the main public healthcare provider and the nationally designated provider for Coronavirus Disease 2019 (COVID-19) healthcare needs. The database covers essentially all serological testing for SARS-CoV-2 conducted in Qatar, including both testing done on residual blood specimens collected for routine clinical care from attendees at HMC [17] and during a series of population-based serological surveys [14, 16].

The antibody database was linked to the HMC national SARS-CoV-2 PCR testing and COVID19 hospitalization and severity database [21]. The latter includes records for all SARS-CoV-2 PCR testing conducted in Qatar since the start of the epidemic. The database also includes all 
medRxiv preprint doi: https://doi.org/10.1101/2021.01.15.21249731; this version posted February 8, 2021. The copyright holder for this preprint (which was not certified by peer review) is the author/funder, who has granted medRxiv a license to display the preprint in perpetuity.

All rights reserved. No reuse allowed without permission.

COVID-19 hospitalizations and their infection severity classifications, assessed through individual chart reviews by trained medical personnel following World Health Organization (WHO) guidelines [22]. Antibody data were also linked to the centralized COVID-19 death registry, which includes all COVID-19 deaths assessed per WHO guidelines [23].

\section{Laboratory methods}

Antibodies against SARS-CoV-2 in serological samples were detected using the Roche Elecsys ${ }^{\circledR}$ Anti-SARS-CoV-2 assay (Roche, Switzerland), an electrochemiluminescence immunoassay that uses a recombinant protein representing the nucleocapsid $(\mathrm{N})$ antigen for antibody binding. Results were interpreted according to the manufacturer's instructions (reactive: optical density (proxy for antibody titer [24]) cutoff index $\geq 1.0$ vs. non-reactive: optical density cutoff index $<1.0)$.

Nasopharyngeal and/or oropharyngeal swabs (Huachenyang Technology, China) were collected for PCR testing and placed in Universal Transport Medium (UTM). Aliquots of UTM were: extracted on the QIAsymphony platform (QIAGEN, USA) and tested with real-time reversetranscription PCR (RT-qPCR) using TaqPath ${ }^{\mathrm{TM}}$ COVID-19 Combo Kits (Thermo Fisher Scientific, USA) on ABI 7500 FAST (Thermo Fisher, USA). Samples were extracted using a custom protocol [25] on a Hamilton Microlab STAR (Hamilton, USA) and tested using AccuPower SARS-CoV-2 Real-Time RT-PCR Kit (Bioneer, Korea) on ABI 7500 FAST, or loaded directly into a Roche cobas ${ }^{\circledR} 6800$ system and assayed with a cobas ${ }^{\circledR}$ SARS-CoV-2 Test (Roche, Switzerland). The first assay targets the viral S, N, and ORF1ab regions. The second targets the virus' RdRp and E-gene regions, and the third targets the ORF1ab and E-gene regions. 
medRxiv preprint doi: https://doi.org/10.1101/2021.01.15.21249731; this version posted February 8, 2021. The copyright holder for this preprint (which was not certified by peer review) is the author/funder, who has granted medRxiv a license to display the preprint in perpetuity.

All rights reserved. No reuse allowed without permission.

All testing was conducted at HMC Central Laboratory or at Sidra Medicine Laboratory, following standardized protocols.

\section{Suspected reinfection case eligibility and classification}

All SARS-CoV-2 antibody-positive persons in Qatar with at least one PCR-positive swab that occurred $\geq 14$ days after the first-positive antibody test were considered as suspected cases of reinfection. These were classified as showing either good evidence, some evidence, or weak (or no) evidence for reinfection based on criteria applied to each case (Box 1). We defined the reinfection $s w a b$ as the first-positive PCR swab that was identified $\geq 14$ days after the firstpositive antibody test. The 14-day cutoff was incorporated to exclude cases in which antibody testing and PCR testing were done around the same time as part of clinical care of COVID-19 patients - a PCR-positive swab within few days of an antibody-positive test is likely to reflect active primary infection under clinical consideration rather than a reinfection.

Suspected reinfection cases with a PCR cycle threshold $(\mathrm{Ct})$ value $\leq 30$ for the reinfection swab (suggestive of a recent active infection) [26-28] and who had not had a PCR-positive swab for 45 days preceding the reinfection swab (to rule out persisting PCR positivity due to non-viable virus fragments) [5, 26, 29-31], were considered as showing good evidence for reinfection.

Suspected reinfection cases who had not had a PCR-positive swab for 45 days preceding the reinfection swab, but whose $\mathrm{Ct}$ value for the reinfection swab was $>30$, were considered as showing some evidence for reinfection.

Suspected reinfection cases who had a PCR-positive swab within the 45 days preceding the reinfection swab were considered as showing weak (or no) evidence for reinfection, as they are 
medRxiv preprint doi: https://doi.org/10.1101/2021.01.15.21249731; this version posted February 8, 2021. The copyright holder for this preprint

(which was not certified by peer review) is the author/funder, who has granted medRxiv a license to display the preprint in perpetuity.

All rights reserved. No reuse allowed without permission.

likely to reflect prolonged PCR positivity of the primary infection rather than a reinfection [5,

26, 29-31].

\section{Viral genome sequencing and analysis}

For a subset of investigated reinfection cases with good or some evidence for reinfection, there were records indicating prior diagnosis of the primary infection. Viral genome sequencing was thus conducted to confirm reinfection in this subset of cases whenever it was possible to retrieve both, the first-infection PCR-positive swab and the reinfection swab. Details of viral genome sequencing methods are provided in Supplementary Text S1.

\section{Reinfection risk and rate}

Risk of documented reinfection was assessed by quantifying the proportion of cases with good or some evidence for reinfection among all eligible anti-SARS-CoV-2 positive cases with an antibody-positive test $\geq 14$ days from end-of-study censoring (excluding cases whose residual blood was tested for antibodies after death).

Incidence rate of documented reinfection was calculated by dividing the number of cases with good or some evidence for reinfection by the number of person-weeks contributed by all antiSARS-CoV-2 positive cases. The follow-up person-time was calculated starting 14 days after the first-positive antibody test until the reinfection swab, all-cause death, or end-of-study censoring (set on December 31, 2020).

Adjusted estimates for the risk of reinfection and the incidence rate of reinfection were derived by applying the confirmation rate obtained from viral genome sequencing analysis.

\section{Comparator antibody-negative group and efficacy of natural infection against reinfection}


medRxiv preprint doi: https://doi.org/10.1101/2021.01.15.21249731; this version posted February 8, 2021. The copyright holder for this preprint (which was not certified by peer review) is the author/funder, who has granted medRxiv a license to display the preprint in perpetuity.

All rights reserved. No reuse allowed without permission.

SARS-CoV-2 incidence was also assessed in the complement cohort including all those testing SARS-CoV-2 antibody-negative in Qatar, to provide an antibody-negative comparator group and to assess the efficacy of natural infection against reinfection.

Both Risk of documented infection and Incidence rate of documented infection in this antibodynegative cohort were assessed as described above for the antibody-positive cohort, but with the event defined here as the first PCR-positive swab that is $\geq 14$ days after the first antibodynegative test.

The efficacy of natural infection against reinfection was estimated by comparing the incidence rate of reinfection in the antibody-positive cohort to the incidence rate of infection in the comparator antibody-negative cohort:

Efficacy against reinfection $=1-\frac{\text { incidence rate of reinfection among the antibody-positive individuals }}{\text { incidence rate of infection mong the antibody-negative individuals }}$.

\section{Ethical approval}

This study was approved by the HMC and Weill Cornell Medicine-Qatar Institutional Review Boards.

\section{RESULTS}

\section{Epidemiological analysis}

The process for selecting suspected cases of SARS-CoV-2 reinfection is shown in Figure 1, which summarizes results of their reinfection status evaluation. Of 192,984 persons tested for anti-SARS-CoV-2 using blood specimens collected between April 16-December 31, 2020, 149,934 had negative test results, and were excluded. Six of the remaining 43,050 antibodypositive persons were also excluded because their residual blood was tested for SARS-CoV-2 
medRxiv preprint doi: https://doi.org/10.1101/2021.01.15.21249731; this version posted February 8, 2021. The copyright holder for this preprint (which was not certified by peer review) is the author/funder, who has granted medRxiv a license to display the preprint in perpetuity.

All rights reserved. No reuse allowed without permission.

antibodies after death. This yielded a retrospective cohort of 43,044 antibody-positive persons for whom possible reinfection was assessed.

The cohort included 8,953 (20.8\%) women and 34,091 men (79.2\%) of 158 nationalities. Median age was 35 years for women (interquartile range (IQR): 28-45 years) and 38 years for men (IQR: 31-47 years). Only 19,976 (46.4\%) of these persons had ever had a PCR-positive swab preceding their first-positive antibody test. Individual time of follow-up ranged between 0 days and 34.6 weeks, with a median of 16.3 weeks.

Only 314 persons had a PCR-positive swab $\geq 14$ days after the first-positive antibody test, and thus qualified for inclusion in the analysis. There were 1,633 swabs (915 positive and 718 negative) collected from these 314 persons, and of these, 1,099 (551 positive and 548 negative) were collected after the first-positive antibody test.

Investigation of these 314 suspected cases of reinfection yielded 32 cases with good evidence for reinfection $(\mathrm{Ct} \leq 30$ for reinfection swab), 97 cases with some evidence $(\mathrm{Ct}>30$ for reinfection swab), while evidence was weak for the remaining 185 cases.

Characteristics of the 129 cases with good or some evidence for reinfection are shown in Table 1. These individuals had a median age of 37 years (range: <1-72 years) and included 92 men (71.3\%). The median time between the first-positive antibody test and the reinfection swab was 52 days (range: 15-212 days). The median $\mathrm{Ct}$ value of the reinfection swab was 32.9 (range: 13.9-38.3). Slightly over a third of cases were diagnosed based on clinical suspicion $(n=34$; $26.4 \%)$ or individual request $(n=9 ; 7.0 \%)$, while the rest $(n=86)$ were identified incidentally either through random PCR-testing campaigns/surveys ( $n=47 ; 36.4 \%)$, through healthcare routine testing $(n=18 ; 14.0 \%)$, through contact tracing $(n=15 ; 11.6 \%)$, or at a port of entry $(n=6$; $4.7 \%)$. 
medRxiv preprint doi: https://doi.org/10.1101/2021.01.15.21249731; this version posted February 8, 2021. The copyright holder for this preprint (which was not certified by peer review) is the author/funder, who has granted medRxiv a license to display the preprint in perpetuity.

All rights reserved. No reuse allowed without permission.

At the time of the reinfection swab, eight cases had records in the severity database. One of these was classified as "severe" and two as "moderate" per WHO classification [22], while the other five were classified as "asymptomatic." At time of primary infection, 14 cases had records in the severity database, one of whom was classified as "critical", three as "severe", five as "moderate", two as "mild", and three as "asymptomatic." For the rest of the reinfection cases, no severity classification was conducted because of minimal or no symptoms to warrant a clinical assessment. For the eight asymptomatic cases above that had a severity assessment, the assessment was conducted because of non-COVID-related hospitalization. No deaths were recorded for any of these reinfection cases.

\section{Confirmation of reinfection through viral genome sequencing}

Among the 129 cases with good or some evidence for reinfection, 62 had records indicating prior diagnosis of a primary infection. Paired specimens of the first-infection PCR-positive swab and the reinfection swab were retrieved in 23 cases. Viral genome sequencing results are summarized in Table 2. Detailed analysis for each genome pair is shown in Figure 2 and Supplementary Figures S1-S2.

There was insufficient evidence to warrant interpretation for seven sample pairs because of low genome quality. For seven additional pairs, there were one to several changes of allele frequency indicative at best of a shifting balance of quasi-species, and thus no evidence for reinfection. For four pairs, there was strong evidence for no reinfection as both genomes were of high quality, yet no differences were found. Three of these cases had a $\mathrm{Ct}<30$ for the reinfection swab, indicating persistent active infection (Table 1). Two of these cases were reported earlier as part of a case report documenting the existence of prolonged infections [32]. 
medRxiv preprint doi: https://doi.org/10.1101/2021.01.15.21249731; this version posted February 8, 2021. The copyright holder for this preprint (which was not certified by peer review) is the author/funder, who has granted medRxiv a license to display the preprint in perpetuity.

All rights reserved. No reuse allowed without permission.

Meanwhile, for one pair, there were few changes of allele frequency offering supporting evidence for reinfection. For four other pairs, there were multiple clear changes of allele frequency indicating strong evidence for reinfection. One of the latter pairs also documented the presence of the D614G mutation (23403bp $\mathrm{A}>\mathrm{G})$ at the reinfection swab - a variant that has progressively replaced the original D614 form [33, 34].

In summary, for the 16 cases where viral genome sequencing evidence was available, five cases were confirmed as reinfections, a confirmation rate of $31.3 \%$. This confirmation rate was similar to that found in our earlier study of reinfection among those with a PCR-confirmed infection at $33.3 \%[5]$.

\section{Assessment of risk and incidence rate of reinfection}

Applying the confirmation rate obtained through viral genome sequencing yielded a risk of documented reinfection of $0.10 \%$ (95\% confidence interval (CI): $0.08-0.11 \%$ ) - that is $31.3 \%$ of 129 reinfections in the cohort of 42,272 anti-SARS-CoV-2 positive persons with an antibodypositive test $\geq 14$ days from end-of-study censoring.

The incidence rate of documented reinfection was estimated at 0.66 per 10,000 person-weeks (95\% CI: $0.56-0.78$ ). That is $31.3 \%$ of 129 reinfection events in a follow-up person-time of 610,832.5 person-weeks.

Figure 3 shows the incidence rate of documented reinfection versus month of follow-up in this cohort of antibody-positive persons. There was evidence for a decreasing trend in the incidence rate of reinfection with each additional month of follow-up (Mantel-Haenszel trend analysis pvalue: <0.001).

\section{Comparator antibody-negative group and efficacy of natural infection against reinfection}


medRxiv preprint doi: https://doi.org/10.1101/2021.01.15.21249731; this version posted February 8, 2021. The copyright holder for this preprint (which was not certified by peer review) is the author/funder, who has granted medRxiv a license to display the preprint in perpetuity.

All rights reserved. No reuse allowed without permission.

The complement cohort of all those testing SARS-CoV-2 antibody-negative included 149,934 individuals. Of those, nine were excluded because their residual blood was tested for SARSCoV-2 antibodies after death. Two other individuals were excluded because their date of death could not be precisely ascertained. This yielded a retrospective cohort of 149,923 antibodynegative persons to be assessed for SARS-CoV-2 infection incidence (Figure 4).

This cohort included 75,904 (50.6\%) women and 74,019 men (49.4\%) of 167 nationalities. Median age was 35 years for women (interquartile range (IQR): 28-47 years) and 39 years for men (IQR: 30-50 years). Individual time of follow-up ranged between 0 days and 45.6 weeks, with a median of 17.0 weeks. These characteristics are similar to those of the antibody-positive cohort apart from the higher proportion of women. The higher proportion of women is a consequence of the fact that men were several-fold more affected than women by the SARSCoV-2 epidemic in Qatar [12, 14, 16, 17], as the men craft and manual worker population, who comprise $60 \%$ of the total population [35], was the most affected with a seroprevalence that is several-fold higher than the rest of the population $[12,14,16,17]$.

Of the 149,923 antibody-negative individuals, 3,185 individuals had at least one PCR-positive swab $\geq 14$ days after the first antibody-negative test. Consequently, the risk of documented infection was estimated at $2.15 \%$ (95\% CI: $2.08-2.22 \%$ ) - that is 3,185 infections in the cohort of 148,181 anti-SARS-CoV-2 negative persons with an antibody-negative test $\geq 14$ days from endof-study censoring.

The incidence rate of documented infection was estimated at 13.69 per 10,000 person-weeks (95\% CI: $13.22-14.14)$, that is 3,185 infections in a follow-up person-time of $2,326,572.0$ personweeks. 
medRxiv preprint doi: https://doi.org/10.1101/2021.01.15.21249731; this version posted February 8, 2021. The copyright holder for this preprint (which was not certified by peer review) is the author/funder, who has granted medRxiv a license to display the preprint in perpetuity.

All rights reserved. No reuse allowed without permission.

The efficacy of natural infection against reinfection was estimated by comparing the incidence rate of reinfection in the antibody-positive cohort to the incidence rate of infection in the comparator antibody-negative cohort:

$$
\text { Efficacy against reinfection }=1-\frac{0.66 \text { per } 10,000 \text { person-weeks }}{13.69 \text { per } 10,000 \text { person-weeks }}
$$

yielding an efficacy estimate of $95.2 \%$ (95\% CI: 94.1-96.0\%).

\section{DISCUSSION}

The results provide concrete evidence for the presence of reinfection in some individuals with detectable antibodies for SARS-CoV-2 infection, even in some with high antibody titers (Table 1). However, the risk of documented reinfection was rare, at $\sim 1$ per 1,000 infected persons, at least for a few months after the first antibody-positive test. There was also no evidence that antibody-positive persons experienced any waning of protective immunity over time, as the incidence rate of reinfection versus month of follow-up did not show an increasing trend over seven months following the first antibody-positive test (Figure 3). To the contrary, there was a trend of decreasing incidence rate, possibly explained by the (very) slowly declining incidence rate in the wider population of Qatar over the last six months $[15,36]$, or possibly by strengthening of protective immunity due to repeated exposures that did not lead to established infection. Notably, a recent study from Qatar indicated an association between higher antibody titers and repeated exposures to the virus [17]. Further follow up of this cohort of antibodypositive persons over time may allow a more long-term assessment of the persistence of protection against reinfection.

Remarkably, the incidence rate of reinfection found here for those with antibody-confirmed infection at $\sim 1$ per 10,000 person-weeks is very similar to that found for those with $P C R$ - 
medRxiv preprint doi: https://doi.org/10.1101/2021.01.15.21249731; this version posted February 8, 2021. The copyright holder for this preprint (which was not certified by peer review) is the author/funder, who has granted medRxiv a license to display the preprint in perpetuity.

All rights reserved. No reuse allowed without permission.

confirmed infection, as reported in our earlier reinfection study [5]. This suggests that these two populations are functionally similar. Evidence of exposure to SARS-CoV-2, regardless of the biomarker used to assess infection, appears sufficient to indicate protection against reinfection.

These findings are striking, as the epidemic in Qatar has been intense, with half of the population estimated to have acquired this infection at some point since its introduction into Qatar early in $2020[14-17,36]$. It is highly probable that a proportion of the population has been repeatedly exposed to SARS-CoV-2, but such re-exposures did not lead to more than a limited number of documentable reinfections. Other lines of evidence also support a low frequency of reinfection. The epidemic in Qatar grew rapidly and declined rapidly $[15,36]$, consistent with a susceptibleinfected-recovered "SIR" epidemic dynamic in which infection elicits strong immunity against reinfection. No second wave has materialized since the epidemic peaked in May of 2020, despite easing of most restrictions $[15,36]$. A recent study on health care workers in the United Kingdom also indicated lower incidence of infection in those antibody-positive [37], and a study of immunological memory in a cohort of COVID-19 patients indicated durability of the immune response for at least 6-8 months [38].

The study estimated the efficacy of natural infection against reinfection at $95.2 \%$ by comparing SARS-CoV-2 incidence in those antibody-positive to those antibody-negative. The efficacy can also be estimated by comparing the incidence rate of documented reinfection to the incidence rate of documented infection throughout the epidemic in the total population of Qatar that was estimated at $\sim 15$ per 10,000 person-weeks [15]. This yielded

$$
\text { Efficacy against reinfection }=1-\frac{0.66 \text { per } 10,000 \text { person-weeks }}{15 \text { per } 10,000 \text { person-weeks }}=95.6 \% \text {, }
$$


medRxiv preprint doi: https://doi.org/10.1101/2021.01.15.21249731; this version posted February 8, 2021. The copyright holder for this preprint (which was not certified by peer review) is the author/funder, who has granted medRxiv a license to display the preprint in perpetuity.

All rights reserved. No reuse allowed without permission.

confirming the same efficacy estimate. Remarkably, this efficacy estimate is similar to the efficacy reported for two recently-developed COVID-19 vaccines [18, 19].

While one reinfection was severe, none were critical or fatal and a large proportion of reinfections were minimally symptomatic (if not asymptomatic) to the extent that they were discovered only incidentally, such as through contact tracing or random testing campaigns/surveys (Table 1). The severity of reinfection was also less than that of primary infection. These findings suggest that reinfections (when they rarely occur) appear well tolerated and no more symptomatic than primary infections.

This study has some limitations. By study design, primary infection was indirectly ascertained through serological testing, thereby including only a subset with documented PCR-confirmed primary infections. Having said so, serological testing was based on a high-quality, validated platform, the Roche platform, one of the best available and most extensively used and investigated commercial platforms, with a specificity of at least $99.8 \%[39,40]$. Thus, it is unlikely that misclassified antibody-positives could have biased our findings. The antibodynegative cohort had a higher proportion of women than the antibody-positive cohort, due to the differential spread of the infection among women versus men in Qatar $[12,14,16,17]$. Viral genome sequencing analysis was possible for only a subset of reinfections, either because primary infection was only identified through antibody testing with no record of earlier PCR testing, or because the reinfection swab could not be retrieved. Reinfections were confirmed by noting differences in the viral genome between the primary infection and the reinfection. While not likely, it is theoretically possible that these differences may have occurred due to within-host evolution of the virus, as in the context of a prolonged infection $[32,41]$. The potential effect of 
these limitations is likely an overestimation, rather than underestimation, of the incidence of reinfection, thereby affirming the conclusion of the rarity of reinfections.

In conclusion, SARS-CoV-2 reinfection was investigated in a large cohort of antibody-positive individuals who were followed for as long as 35 weeks. While the study documented some reinfections, they constitute a rare phenomenon, with natural infection eliciting protection against reinfection with an efficacy of $\sim 95 \%$. This points to development of robust immunity following primary infection, which lasts for at least seven months. These findings may suggest that prioritizing vaccination for those who are antibody-negative, as long as doses of the vaccine remain in short supply, could enhance the health, societal, and economic gains attained by vaccination. 
medRxiv preprint doi: https://doi.org/10.1101/2021.01.15.21249731; this version posted February 8, 2021. The copyright holder for this preprint (which was not certified by peer review) is the author/funder, who has granted medRxiv a license to display the preprint in perpetuity.

All rights reserved. No reuse allowed without permission.

\section{Funding}

The authors are grateful for support from the Biomedical Research Program, the Biostatistics, Epidemiology, and Biomathematics Research Core, and the Genomics Core, all at Weill Cornell Medicine-Qatar, as well as for support provided by the Ministry of Public Health and Hamad Medical Corporation. The authors are also grateful for support from the Qatar Genome Programme for supporting the viral genome sequencing. The statements made herein are solely the responsibility of the authors.

\section{Acknowledgements}

We thank Her Excellency Dr. Hanan Al Kuwari, Minister of Public Health, for her vision, guidance, leadership, and support. We also thank Dr. Saad Al Kaabi, Chair of the System Wide Incident Command and Control (SWICC) Committee for the COVID-19 national healthcare response, for his leadership, analytical insights, and for his instrumental role in enacting data information systems that made these studies possible. We further extend our appreciation to the SWICC Committee and the Scientific Reference and Research Taskforce (SRRT) members for their informative input, scientific technical advice, and enriching discussions. We also thank Dr. Mariam Abdulmalik, CEO of the Primary Health Care Corporation and the Chairperson of the Tactical Community Command Group on COVID-19, as well as members of this committee, for providing support to the teams that worked on the field surveillance. We further thank Dr. Nahla Afifi, Director of Qatar Biobank (QBB), Ms. Tasneem Al-Hamad, Ms. Eiman Al-Khayat and the rest of the QBB team for their unwavering support in retrieving and analyzing samples and in compiling and generating databases for COVID-19 infection, as well as Dr. Asmaa Al-Thani, Chairperson of the Qatar Genome Programme Committee and Board Vice Chairperson of QBB, for her leadership of this effort. We also acknowledge the dedicated efforts of the Clinical 
medRxiv preprint doi: https://doi.org/10.1101/2021.01.15.21249731; this version posted February 8, 2021. The copyright holder for this preprint (which was not certified by peer review) is the author/funder, who has granted medRxiv a license to display the preprint in perpetuity.

All rights reserved. No reuse allowed without permission.

Coding Team and the COVID-19 Mortality Review Team, both at Hamad Medical Corporation, and the Surveillance Team at the Ministry of Public Health.

\section{Author contributions}

LJA conceived and designed the study, led the statistical analyses, and co-wrote the first draft of the article. HC contributed to study design, performed the data analyses, and co-wrote the first draft of the article. JAM led the viral genome sequencing analyses and AAA, YAM, and SY conducted these analyses. All authors contributed to data collection and acquisition, database development, discussion and interpretation of the results, and to the writing of the manuscript. All authors have read and approved the final manuscript.

\section{Competing interests}

We declare no competing interests.

\section{Data sharing}

All relevant data are available within the manuscript and its supplementary materials. 
medRxiv preprint doi: https://doi.org/10.1101/2021.01.15.21249731; this version posted February 8, 2021. The copyright holder for this preprint (which was not certified by peer review) is the author/funder, who has granted medRxiv a license to display the preprint in perpetuity.

All rights reserved. No reuse allowed without permission.

\section{References}

1. World Health Organization (WHO), WHO Director-General's opening remarks at the media briefing on COVID-19 - 11 March 2020. Available from: https://www.who.int/dg/speeches/detail/who-director-general-s-opening-remarks-at-themedia-briefing-on-covid-19---11-march-2020. Accessed on March 14, 2020. 2020.

2. De Walque D., et al., How two tests can help contain COVID-19 and revive the economy. Available from: http://documents.worldbank.org/curated/en/766471586360658318/pdf/HowTwo-Tests-Can-Help-Contain-COVID-19-and-Revive-the-Economy.pdf. Accessed on April 16, 2020. Research \& Policy Briefs, World Bank Malaysia Hub., 2020.

3. Kaplan J., Frias L., and McFall-Johnsen M., A third of the global population is on coronavirus lockdown. Available from: https://www. businessinsider.com.au/countries-on-lockdowncoronavirus-italy-2020-3 Accessd on: April 25, 2020. Business Insider Australia, 2020.

4. Nicola, M., et al., The socio-economic implications of the coronavirus pandemic (COVID-19): A review. Int J Surg, 2020. 78: p. 185-193.

5. Abu-Raddad, L.J., et al., Assessment of the risk of SARS-CoV-2 reinfection in an intense reexposure setting. Clinical Infectious Diseases, 2020. ciaa1846. doi: 10.1093/cid/ciaa1846. .

6. Tillett, R.L., et al., Genomic evidence for reinfection with SARS-CoV-2: a case study. Lancet Infect Dis, 2020.

7. To, K.K., et al., COVID-19 re-infection by a phylogenetically distinct SARS-coronavirus-2 strain confirmed by whole genome sequencing. Clin Infect Dis, 2020.

8. Van Elslande, J., et al., Symptomatic SARS-CoV-2 reinfection by a phylogenetically distinct strain. Clin Infect Dis, 2020.

9. Prado-Vivar B., et al., COVID-19 re-infection by a phylogenetically distinct SARS-CoV-2 variant, first confirmed event in South America. SSRN. 2020; (published online Sept 8.) (preprint) https://doi.org/10.2139/ssrn.3686174.

10. Planning and Statistics Authority- State of Qatar, Qatar Monthly Statistics. Available from: https://www.psa.gov.qa/en/pages/default.aspx. Accessed on: may 26,2020. 2020.

11. Planning and Statistics Authority-State of Qatar, The Simplified Census of Population, Housing \& Establishments. Available from: https://www.psa.gov.qa/en/statistics/Statistical\%20Releases/Population/Population/2018/Pop ulation social 12018 AE.pdf Accessed on: April 2, 2020. 2019.

12. Abu-Raddad, L.J., et al., Characterizing the Qatar advanced-phase SARS-CoV-2 epidemic. medRxiv, 2020: p. 2020.07.16.20155317v2 (non-peer-reviewed preprint).

13. Al Kuwari, H.M., et al., Epidemiological investigation of the first 5685 cases of SARS-CoV-2 infection in Qatar, 28 February-18 April 2020. BMJ Open, 2020. 10(10): p. e040428.

14. Al-Thani, M.H., et al., Seroprevalence of SARS-CoV-2 infection in the craft and manual worker population of Qatar. medRxiv, 2020: p. 2020.11.24.20237719 (non-peer-reviewed preprint).

15. Ayoub, H.H., et al., Mathematical modeling of the SARS-CoV-2 epidemic in Qatar and its impact on the national response to COVID-19. Journal of Global Health, 2021. 11: p. 05005.

16. Jeremijenko, A., et al., Evidence for and level of herd immunity against SARS-CoV-2 infection: the ten-community study. medRxiv, 2020: p. 2020.09.24.20200543 (non-peer-reviewed preprint).

17. Coyle, P.V., et al., SARS-CoV-2 seroprevalence in the urban population of Qatar: An analysis of antibody testing on a sample of 112,941 individuals. medRxiv, 2021: p. 2021.01.05.21249247.

18. Polack, F.P., et al., Safety and Efficacy of the BNT162b2 mRNA Covid-19 Vaccine. N Engl J Med, 2020.

19. Jackson, L.A., et al., An mRNA Vaccine against SARS-CoV-2 - Preliminary Report. N Engl J Med, 2020. 383(20): p. 1920-1931. 
medRxiv preprint doi: https://doi.org/10.1101/2021.01.15.21249731; this version posted February 8, 2021. The copyright holder for this preprint (which was not certified by peer review) is the author/funder, who has granted medRxiv a license to display the preprint in perpetuity.

All rights reserved. No reuse allowed without permission.

20. Voysey, M., et al., Safety and efficacy of the ChAdOx1 nCoV-19 vaccine (AZD1222) against SARSCoV-2: an interim analysis of four randomised controlled trials in Brazil, South Africa, and the UK. Lancet, 2020.

21. Hamad Medical Corporation, National SARS-CoV-2 PCR testing, infection severity, and hospitalization database. 2020.

22. World Health Organization, Clinical management of COVID-19. Available from: https://www.who.int/publications-detail/clinical-management-of-covid-19. Accessed on: May 31st 2020. 2020.

23. World Health Organization, International guidelines for certification and classification (coding) of COVID-19 as cause of death. Available from: https://www.who.int/classifications/icd/Guidelines Cause of Death COVID-19-20200420EN.pdf?ua=1. Document Number: WHO/HQ/DDI/DNA/CAT. Accessed on June 1, 2020. . 2020.

24. Oved, K., et al., Multi-center nationwide comparison of seven serology assays reveals a SARSCoV-2 non-responding seronegative subpopulation. EClinicalMedicine, 2020. 29: p. 100651.

25. Kalikiri, M.K.R., et al., High-throughput extraction of SARS-CoV-2 RNA from nasopharyngeal swabs using solid-phase reverse immobilization beads. medRxiv, 2020: p. 2020.04.08.20055731.

26. Sethuraman, N., S.S. Jeremiah, and A. Ryo, Interpreting Diagnostic Tests for SARS-CoV-2. JAMA, 2020. 323(22): p. 2249-2251.

27. Singanayagam, A., et al., Duration of infectiousness and correlation with RT-PCR cycle threshold values in cases of COVID-19, England, January to May 2020. Euro Surveill, 2020. 25(32).

28. Drew, R.J., et al., The importance of cycle threshold values in interpreting molecular tests for SARS-CoV-2. Diagn Microbiol Infect Dis, 2020. 98(3): p. 115130.

29. Wajnberg, A., et al., Humoral response and PCR positivity in patients with COVID-19 in the New York City region, USA: an observational study. Lancet Microbe, 2020. 1(7): p. e283-e289.

30. Cha S. and Smith J., Explainer: South Korean findings suggest 'reinfected' coronavirus cases are false positives. Reuters. Available from: https://www.reuters.com/article/us-health-coronavirussouthkorea-explain-idUSKBN22JOHR. Accessed on: November 24, 2020, 2020.

31. Bo-gyung K., Tests in recovered patients found false positives, not reinfections, experts say. The Korea Herald. Available from: http://www.koreaherald.com/view.php?ud=20200429000724. Accessed on November 24, 2020, 2020.

32. Abu-Raddad, L.J., et al., Two prolonged viremic SARS-CoV-2 infections with conserved viral genome for two months. Infect Genet Evol, 2020. 88: p. 104684.

33. Korber, B., et al., Tracking Changes in SARS-CoV-2 Spike: Evidence that D614G Increases Infectivity of the COVID-19 Virus. Cell, 2020. 182(4): p. 812-827 e19.

34. Grubaugh, N.D., W.P. Hanage, and A.L. Rasmussen, Making Sense of Mutation: What D614G Means for the COVID-19 Pandemic Remains Unclear. Cell, 2020. 182(4): p. 794-795.

35. Planning and Statistics Authority- State of Qatar, Labor force sample survey. Available from: https://www.psa.gov.qa/en/statistics/Statistical\%20Releases/Social/LaborForce/2017/statistical analysis labor force 2017 En.pdf. Accessed on: May 01, 2020. 2017.

36. Seedat, S., et al., SARS-CoV-2 infection hospitalization, severity, criticality, and fatality rates. medRxiv 2020.11.29.20240416 (non-peer-reviewed preprint), 2020.

37. Lumley, S.F., et al., Antibody Status and Incidence of SARS-CoV-2 Infection in Health Care Workers. N Engl J Med, 2020.

38. Dan, J.M., et al., Immunological memory to SARS-CoV-2 assessed for up to 8 months after infection. Science, 2021.

39. The Roche Group, Roche's COVID-19 antibody test receives FDA Emergency Use Authorization and is available in markets accepting the CE mark. Available from: 
medRxiv preprint doi: https://doi.org/10.1101/2021.01.15.21249731; this version posted February 8, 2021. The copyright holder for this preprint (which was not certified by peer review) is the author/funder, who has granted medRxiv a license to display the preprint in perpetuity. All rights reserved. No reuse allowed without permission.

https://www.roche.com/media/releases/med-cor-2020-05-03.htm. Accessed on: June 5, 2020. 2020.

40. Public Health England, Evaluation of Roche Elecsys AntiSARS-CoV-2 serology assay for the detection of anti-SARS-CoV-2 antibodies. Available from:

https://assets.publishing.service.gov.uk/government/uploads/system/uploads/attachment data Afile/891598/Evaluation of Roche Elecsys anti SARS COV 2 PHE 200610 V8.1 FINAL.pdf. Accessed on June 5, 2020. 2020.

41. European Centre for Disease Prevention and Control, Rapid increase of a SARS-CoV-2 variant with multiple spike protein mutations observed in the United Kingdom-20 December 2020. Available from: https://www.ecdc.europa.eu/sites/default/files/documents/SARS-CoV-2-variantmultiple-spike-protein-mutations-United-Kingdom.pdf. Accessed on: January 7, 2021. 2020: ECDC: Stockholm. 
medRxiv preprint doi: https://doi.org/10.1101/2021.01.15.21249731; this version posted February 8, 2021. The copyright holder for this preprint

(which was not certified by peer review) is the author/funder, who has granted medRxiv a license to display the preprint in perpetuity.

All rights reserved. No reuse allowed without permission.

\title{
Box 1. Classification of suspected cases of SARS-CoV-2 reinfection based on the strength of supporting epidemiological evidence.
}

\author{
Suspected cases of SARS-CoV-2 reinfection: All antibody-positive persons with at least one PCR-positive swab \\ that occurred $\geq 14$ days after the first-positive antibody test. \\ Good evidence for reinfection: Individuals who had a PCR-positive swab with a Ct value $\leq 30$ at least 14 days \\ after the first-positive antibody test and who had not had a PCR-positive swab within the 45 days preceding the \\ reinfection swab. \\ Some evidence for reinfection: Individuals who had a PCR-positive swab with a Ct value $>30$ at least 14 days \\ after the first-positive antibody test and who had not had a PCR-positive swab within the 45 days preceding the \\ reinfection swab. \\ Weak evidence for reinfection: Individuals who had a PCR-positive swab at least 14 days after the first-positive \\ antibody test, but who had one or more PCR-positive swabs within the 45 days preceding the reinfection swab.
}

$\mathrm{Ct}$, cycle threshold; PCR, polymerase chain reaction. 
medRxiv preprint doi: https://doi.org/10.1101/2021.01.15.21249731; this version posted February 8, 2021. The copyright holder for this preprint (which was not certified by peer review) is the author/funder, who has granted medRxiv a license to display the preprint in perpetuity.

All rights reserved. No reuse allowed without permission.

Figure 1. Flow chart describing the selection process of suspected cases of SARS-CoV-2 reinfection and summarizing the results of their reinfection status' evaluation.

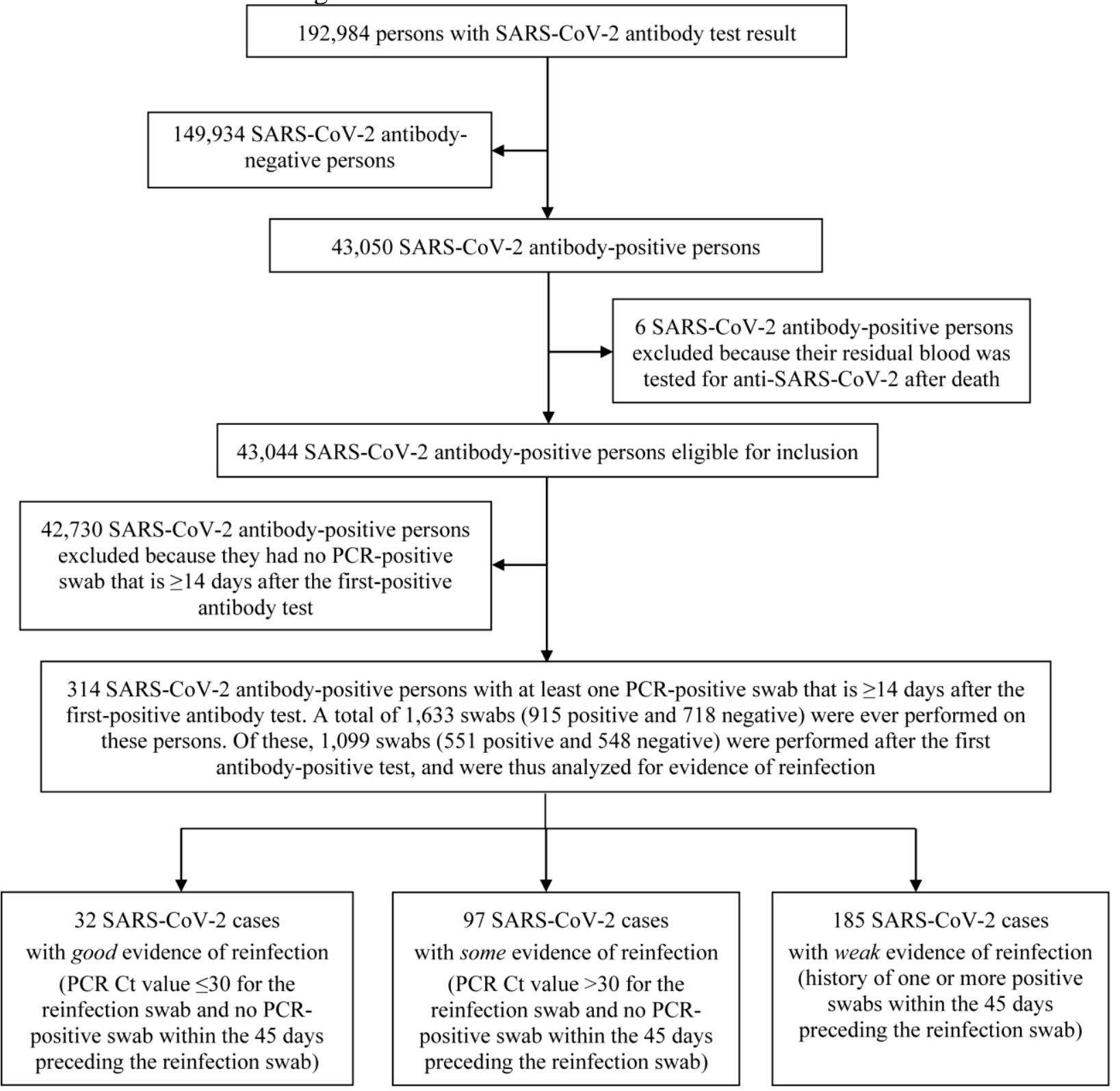

${ }^{*} \mathrm{Ct}$, cycle threshold; PCR, polymerase chain reaction 
medRxiv preprint doi: https://doi.org/10.1101/2021.01.15.21249731; this version posted February 8, 2021. The copyright holder for this preprint (which was not certified by peer review) is the author/funder, who has granted medRxiv a license to display the preprint in perpetuity. All rights reserved. No reuse allowed without permission.

Table 1. Characteristics of individuals classified as showing good or some evidence of reinfection.

\begin{tabular}{|c|c|c|c|c|c|c|c|c|}
\hline \multirow{2}{*}{ ID\# } & \multicolumn{2}{|c|}{ Demography } & \multicolumn{2}{|c|}{ Ab testing } & \multicolumn{4}{|l|}{ PCR testing } \\
\hline & Sex & $\begin{array}{l}\text { Age } \\
\text { group }\end{array}$ & $\begin{array}{l}\text { First- } \\
\text { positive } \\
\text { Ab test } \\
\text { date }\end{array}$ & $\begin{array}{l}\text { Ab test } \\
\text { optical } \\
\text { density } \\
\text { (Ab titers) }\end{array}$ & $\begin{array}{l}\text { Reinfection } \\
\text { swab date }\end{array}$ & $\begin{array}{l}\text { Average } \\
\text { Ct } \\
\text { value* }\end{array}$ & Reason for swab & $\begin{array}{l}\text { Presence of } \\
\text { symptoms }\end{array}$ \\
\hline \multicolumn{9}{|c|}{ Good evidence for reinfection } \\
\hline 1 & Female & $10-14$ & Day 0 & 1.1 & Day 63 & 21.7 & Clinical suspicion $\$$ & Yes \\
\hline 2 & Female & $20-24$ & Day 0 & 1.2 & Day 91 & 16.6 & Contact tracing & Yes \\
\hline 3 & Male & $50-54$ & Day 0 & 1.2 & Day 49 & 22.0 & Clinical suspicion ${ }^{\S}$ & Yes \\
\hline 4 & Female & $25-29$ & Day 0 & 1.4 & Day 34 & 30.0 & Individual request $^{\dagger}$ & No \\
\hline 5 & Female & $40-44$ & Day 0 & 2.0 & Day 75 & 22.2 & Individual request $^{\dagger}$ & Yes \\
\hline 6 & Male & $30-34$ & Day 0 & 2.1 & Day 71 & 29.5 & Clinical suspicion ${ }^{\S}$ & $\mathrm{No}^{\dagger \dagger}$ \\
\hline 7 & Female & $30-34$ & Day 0 & 2.3 & Day 64 & 21.8 & Clinical suspicion ${ }^{\S}$ & Yes \\
\hline 8 & Female & $40-44$ & Day 0 & 2.4 & Day 36 & 20.5 & Port of entry & No \\
\hline 9 & Female & $20-24$ & Day 0 & 2.7 & Day 89 & 20.5 & Contact tracing & No \\
\hline 10 & Male & $30-34$ & Day 0 & 3.0 & Day 37 & 28.1 & Clinical suspicion ${ }^{\S}$ & $\mathrm{No}^{\dagger \dagger}$ \\
\hline 11 & Female & $30-34$ & Day 0 & 3.0 & Day 147 & 28.0 & Clinical suspicion ${ }^{\S}$ & Yes \\
\hline 12 & Male & $40-44$ & Day 0 & 4.8 & Day 25 & 22.6 & Survey $^{* * *}$ & No \\
\hline 13 & Male & $35-39$ & Day 0 & 5.6 & Day 85 & 23.3 & Survey $^{* *}$ & Not indicated \\
\hline 14 & Male & $30-34$ & Day 0 & 7.6 & Day 63 & 29.5 & Clinical suspicion ${ }^{\S}$ & $\mathrm{No}^{\dagger \dagger}$ \\
\hline 15 & Female & $40-44$ & Day 0 & 7.7 & Day 75 & 23.4 & Contact tracing & No \\
\hline 16 & Female & $30-34$ & Day 0 & 8.7 & Day 122 & 13.9 & Survey ${ }^{* *}$ & Not indicated \\
\hline 17 & Male & $55-59$ & Day 0 & 8.8 & Day 45 & 26.4 & Clinical suspicion ${ }^{\S}$ & $\mathrm{No}^{\dagger \dagger}$ \\
\hline 18 & Male & $50-54$ & Day 0 & 9.2 & Day 126 & 29.8 & Individual request $^{\dagger}$ & No \\
\hline 19 & Male & $40-44$ & Day 0 & 11.3 & Day 100 & 28.1 & Clinical suspicion ${ }^{\S}$ & Yes \\
\hline 20 & Male & $35-39$ & Day 0 & 11.3 & Day 68 & 28.1 & Contact tracing & Not indicated \\
\hline 21 & Male & $35-39$ & Day 0 & 14.9 & Day 53 & 28.8 & Survey $^{* *}$ & No \\
\hline 22 & Female & $0-9$ & Day 0 & 16.7 & Day 74 & 29.5 & Clinical suspicion ${ }^{\S}$ & Yes \\
\hline 23 & Male & $40-44$ & Day 0 & 22.2 & Day 109 & 24.4 & Port of entry & No \\
\hline 24 & Female & $25-29$ & Day 0 & 24.2 & Day 40 & 29.5 & Clinical suspicion ${ }^{\S}$ & $\mathrm{No}^{\dagger \dagger}$ \\
\hline 25 & Female & $20-24$ & Day 0 & 25.9 & Day 36 & 29.1 & Survey ${ }^{* *}$ & No \\
\hline 26 & Male & $65-69$ & Day 0 & 28.3 & Day 21 & 27.7 & Clinical suspicion ${ }^{\S}$ & Not indicated \\
\hline 27 & Male & $50-54$ & Day 0 & 32.0 & Day 89 & 29.2 & Healthcare routine testing & No \\
\hline 28 & Male & $65-69$ & Day 0 & 55.9 & Day 58 & 29.4 & Healthcare routine testing & No \\
\hline 29 & Male & $35-39$ & Day 0 & 75.4 & Day 36 & 37.6 & Survey ${ }^{* *}$ & No \\
\hline 30 & Male & $55-59$ & Day 0 & 85.6 & Day 111 & 27.8 & Survey $^{* *}$ & No \\
\hline 31 & Female & $30-34$ & Day 0 & 60.1 & Day 65 & 29.1 & Individual request $^{\dagger}$ & Yes \\
\hline 32 & Male & $20-24$ & Day 0 & 140.0 & Day 17 & 30.0 & Clinical suspicion ${ }^{\S}$ & $\mathrm{No}^{\dagger \dagger}$ \\
\hline \multicolumn{9}{|c|}{ Some evidence of reinfection } \\
\hline 33 & Female & $40-44$ & Day 0 & 1.1 & Day 33 & 36.2 & Survey $^{* *}$ & No \\
\hline 34 & Male & $20-24$ & Day 0 & 1.1 & Day 30 & NR & Contact tracing & No \\
\hline 35 & Male & $30-34$ & Day 0 & 1.2 & Day 125 & NR & Clinical suspicion ${ }^{\S}$ & Yes \\
\hline 36 & Male & $25-29$ & Day 0 & 1.6 & Day 27 & NR & Survey ${ }^{* *}$ & No \\
\hline 37 & Male & $30-34$ & Day 0 & 1.7 & Day 56 & NR & Clinical suspicion ${ }^{\S}$ & $\mathrm{No}^{\dagger \dagger}$ \\
\hline 38 & Female & $45-49$ & Day 0 & 2.0 & Day 54 & NR & Healthcare routine testing & No \\
\hline 39 & Female & $65-69$ & Day 0 & 2.0 & Day 49 & NR & Survey $^{* *}$ & No \\
\hline 40 & Male & $60-64$ & Day 0 & 2.5 & Day 88 & NR & Healthcare routine testing & No \\
\hline 41 & Female & $40-44$ & Day 0 & 3.4 & Day 65 & NR & Survey $^{* *}$ & Not indicated \\
\hline 42 & Male & $35-39$ & Day 0 & 3.7 & Day 82 & NR & Clinical suspicion ${ }^{\S}$ & $\mathrm{No}^{\dagger \dagger}$ \\
\hline 43 & Male & $45-49$ & Day 0 & 3.9 & Day 36 & 30.5 & Clinical suspicion $\$$ & $\mathrm{No}^{\dagger \dagger}$ \\
\hline 44 & Female & $20-24$ & Day 0 & 4.1 & Day 19 & 35.9 & Survey $^{* *}$ & No \\
\hline 45 & Female & $45-49$ & Day 0 & 4.5 & Day 63 & 31.0 & Clinical suspicion ${ }^{\S}$ & Yes \\
\hline 46 & Male & $60-64$ & Day 0 & 5.2 & Day 65 & NR & Clinical suspicion ${ }^{\S}$ & $\mathrm{No}^{\dagger \dagger}$ \\
\hline 47 & Male & $50-54$ & Day 0 & 5.7 & Day 80 & 31.3 & Port of entry & No \\
\hline 48 & Female & $40-44$ & Day 0 & 6.2 & Day 16 & 33.9 & Port of entry & Yes \\
\hline 49 & Male & $35-39$ & Day 0 & 6.3 & Day 118 & 31.5 & Survey $^{* *}$ & No \\
\hline 50 & Male & $25-29$ & Day 0 & 6.9 & Day 88 & 32.8 & Clinical suspicion $\$$ & $\mathrm{No}^{\dagger \dagger}$ \\
\hline
\end{tabular}


medRxiv preprint doi: https://doi.org/10.1101/2021.01.15.21249731; this version posted February 8, 2021. The copyright holder for this preprint (which was not certified by peer review) is the author/funder, who has granted medRxiv a license to display the preprint in perpetuity. All rights reserved. No reuse allowed without permission.

\begin{tabular}{|c|c|c|c|c|c|c|c|c|}
\hline \multirow[b]{2}{*}{ ID\# } & \multicolumn{2}{|c|}{ Demography } & \multicolumn{2}{|c|}{ Ab testing } & \multicolumn{4}{|l|}{ PCR testing } \\
\hline & Sex & $\begin{array}{l}\text { Age } \\
\text { group }\end{array}$ & $\begin{array}{l}\text { First- } \\
\text { positive } \\
\text { Ab test } \\
\text { date } \\
\end{array}$ & $\begin{array}{l}\text { Ab test } \\
\text { optical } \\
\text { density } \\
\text { (Ab titers) }\end{array}$ & $\begin{array}{l}\text { Reinfection } \\
\text { swab date }\end{array}$ & $\begin{array}{l}\text { Average } \\
\text { Ct } \\
\text { value* }\end{array}$ & Reason for swab & $\begin{array}{l}\text { Presence of } \\
\text { symptoms }\end{array}$ \\
\hline 51 & Male & $50-54$ & Day 0 & 7.6 & Day 28 & 36.4 & Survey $^{* *}$ & No \\
\hline 52 & Male & $50-54$ & Day 0 & 7.7 & Day 103 & NR & Contact tracing & No \\
\hline 53 & Male & $35-39$ & Day 0 & 7.9 & Day 125 & NR & Survey** & No \\
\hline 54 & Male & $40-44$ & Day 0 & 8.0 & Day 73 & 34.1 & Survey** & No \\
\hline 55 & Female & $25-29$ & Day 0 & 9.0 & Day 15 & 34.2 & Healthcare routine testing & Not indicated \\
\hline 56 & Male & $40-44$ & Day 0 & 9.9 & Day 43 & 32.9 & Survey ${ }^{* *}$ & No \\
\hline 57 & Female & $30-34$ & Day 0 & 10.8 & Day 76 & 30.2 & Clinical suspicion ${ }^{\S}$ & $\mathrm{No}^{\dagger i}$ \\
\hline 58 & Male & $25-29$ & Day 0 & 11.0 & Day 35 & 37.4 & Survey** & Not indicated \\
\hline 59 & Female & $45-49$ & Day 0 & 11.0 & Day 81 & NR & Contact tracing & No \\
\hline 60 & Male & $50-54$ & Day 0 & 13.1 & Day 90 & NR & Contact tracing & No \\
\hline 61 & Male & $35-39$ & Day 0 & 13.2 & Day 17 & 36.8 & Healthcare routine testing & No \\
\hline 62 & Male & $40-44$ & Day 0 & 13.5 & Day 212 & NR & Survey** & No \\
\hline 63 & Female & $50-54$ & Day 0 & 14.5 & Day 38 & 32.3 & Survey ${ }^{* *}$ & No \\
\hline 64 & Female & $35-39$ & Day 0 & 14.8 & Day 57 & NR & Individual request ${ }^{\dagger}$ & No \\
\hline 65 & Female & $35-39$ & Day 0 & 15.8 & Day 17 & NR & Contact tracing & No \\
\hline 66 & Male & $45-49$ & Day 0 & 16.0 & Day 99 & NR & Healthcare routine testing & No \\
\hline 67 & Female & $30-34$ & Day 0 & 16.6 & Day 18 & 36.2 & Survey ${ }^{* *}$ & No \\
\hline 68 & Male & $60-64$ & Day 0 & 17.3 & Day 50 & 31.0 & Healthcare routine testing & No \\
\hline 69 & Male & $35-39$ & Day 0 & 17.4 & Day 25 & 33.7 & Survey** & Not indicated \\
\hline 70 & Male & $25-29$ & Day 0 & 17.8 & Day 30 & NR & Clinical suspicion ${ }^{\S}$ & $\mathrm{No}^{\dagger i}$ \\
\hline 71 & Male & $35-39$ & Day 0 & 18.0 & Day 48 & NR & Survey $^{* *}$ & Not indicated \\
\hline 72 & Male & $35-39$ & Day 0 & 19.7 & Day 83 & NR & Survey** & No \\
\hline 73 & Male & $15-19$ & Day 0 & 20.0 & Day 35 & 34.5 & Healthcare routine testing & No \\
\hline 74 & Male & $50-54$ & Day 0 & 20.1 & Day 64 & NR & Clinical suspicion ${ }^{\S}$ & $\mathrm{No}^{\dagger \dagger}$ \\
\hline 75 & Male & $40-44$ & Day 0 & 20.5 & Day 52 & NR & Clinical suspicion ${ }^{\S}$ & $\mathrm{No}^{\dagger i}$ \\
\hline 76 & Female & $35-39$ & Day 0 & 20.9 & Day 45 & NR & Survey ${ }^{* *}$ & No \\
\hline 77 & Male & $20-24$ & Day 0 & 20.9 & Day 98 & 34.9 & Survey** & No \\
\hline 78 & Male & $45-49$ & Day 0 & 22.9 & Day 31 & 34.7 & Survey** & No \\
\hline 79 & Male & $50-54$ & Day 0 & 26.9 & Day 31 & 35.3 & Survey** & No \\
\hline 80 & Male & $20-24$ & Day 0 & 28.5 & Day 56 & 33.0 & Survey** & No \\
\hline 81 & Male & $30-34$ & Day 0 & 28.5 & Day 45 & 34.9 & Clinical suspicion ${ }^{\S}$ & Yes \\
\hline 82 & Male & $30-34$ & Day 0 & 30.4 & Day 18 & 35.3 & Survey ${ }^{* *}$ & Not indicated \\
\hline 83 & Male & $40-44$ & Day 0 & 31.9 & Day 99 & NR & Individual request ${ }^{\dagger}$ & No \\
\hline 84 & Male & $0-9$ & Day 0 & 32.8 & Day 31 & NR & Clinical suspicion ${ }^{\S}$ & Yes \\
\hline 85 & Male & $70-74$ & Day 0 & 33.2 & Day 49 & NR & Healthcare routine testing & No \\
\hline 86 & Male & $40-44$ & Day 0 & 35.8 & Day 56 & NR & Survey $^{* *}$ & No \\
\hline 87 & Male & $30-34$ & Day 0 & 36.8 & Day 53 & NR & Survey** & No \\
\hline 88 & Male & $30-34$ & Day 0 & 37.9 & Day 61 & NR & Clinical suspicion ${ }^{\S}$ & Yes \\
\hline 89 & Female & $25-29$ & Day 0 & 38.3 & Day 47 & 36.0 & Survey $^{* *}$ & No \\
\hline 90 & Male & $30-34$ & Day 0 & 39.6 & Day 15 & 34.2 & Contact tracing & No \\
\hline 91 & Male & $30-34$ & Day 0 & 41.9 & Day 15 & 34.4 & Survey** & No \\
\hline 92 & Female & $35-39$ & Day 0 & 43.2 & Day 50 & NR & Healthcare routine testing & No \\
\hline 93 & Male & $25-29$ & Day 0 & 46.0 & Day 41 & 31.6 & Contact tracing & Not indicated \\
\hline 94 & Male & $20-24$ & Day 0 & 46.2 & Day 80 & 33.0 & Healthcare routine testing & No \\
\hline 95 & Male & $60-64$ & Day 0 & 47.0 & Day 24 & 31.3 & Survey*** & No \\
\hline 96 & Male & $25-29$ & Day 0 & 47.8 & Day 15 & NR & Survey** & No \\
\hline 97 & Male & $40-44$ & Day 0 & 48.3 & Day 48 & NR & Survey ${ }^{* *}$ & No \\
\hline 98 & Male & $35-39$ & Day 0 & 49.4 & Day 32 & 33.6 & Survey** & Not indicated \\
\hline 99 & Male & $25-29$ & Day 0 & 51.7 & Day 55 & 33.6 & Clinical suspicion $\S$ & $\mathrm{No}^{\dagger \dagger}$ \\
\hline 100 & Female & $10-14$ & Day 0 & 52.4 & Day 78 & 42.4 & Individual request ${ }^{\dagger}$ & Not indicated \\
\hline 101 & Male & $30-34$ & Day 0 & 54.4 & Day 15 & 35.9 & Survey ${ }^{* *}$ & No \\
\hline 102 & Male & $35-39$ & Day 0 & 55.1 & Day 91 & 37.5 & Clinical suspicion $\S$ & Yes \\
\hline 103 & Male & $35-39$ & Day 0 & 56.1 & Day 41 & 36.2 & Survey ${ }^{* *}$ & No \\
\hline 104 & Male & $40-44$ & Day 0 & 57.2 & Day 70 & 36.7 & Clinical suspicion ${ }^{\S}$ & Yes \\
\hline
\end{tabular}


medRxiv preprint doi: https://doi.org/10.1101/2021.01.15.21249731; this version posted February 8, 2021. The copyright holder for this preprint (which was not certified by peer review) is the author/funder, who has granted medRxiv a license to display the preprint in perpetuity. All rights reserved. No reuse allowed without permission.

\begin{tabular}{|c|c|c|c|c|c|c|c|c|}
\hline \multirow[b]{2}{*}{ ID\# } & \multicolumn{2}{|c|}{ Demography } & \multicolumn{2}{|c|}{ Ab testing } & \multicolumn{4}{|l|}{ PCR testing } \\
\hline & Sex & $\begin{array}{l}\text { Age } \\
\text { group }\end{array}$ & $\begin{array}{l}\text { First- } \\
\text { positive } \\
\text { Ab test } \\
\text { date }\end{array}$ & $\begin{array}{l}\text { Ab test } \\
\text { optical } \\
\text { density } \\
\text { (Ab titers) }\end{array}$ & $\begin{array}{l}\text { Reinfection } \\
\text { swab date }\end{array}$ & $\begin{array}{l}\text { Average } \\
\text { Ct } \\
\text { value }^{*}\end{array}$ & Reason for swab & $\begin{array}{l}\text { Presence of } \\
\text { symptoms }\end{array}$ \\
\hline 105 & Male & $50-54$ & Day 0 & 57.4 & Day 98 & 37.3 & Healthcare routine testing & No \\
\hline 106 & Female & $15-19$ & Day 0 & 63.8 & Day 65 & NR & Individual request $^{\dagger}$ & No \\
\hline 107 & Female & $30-34$ & Day 0 & 65.0 & Day 61 & 36.4 & Port of entry ${ }^{\ddagger}$ & No \\
\hline 108 & Male & $25-29$ & Day 0 & 65.3 & Day 33 & NR & Contact tracing & No \\
\hline 109 & Male & $45-49$ & Day 0 & 66.8 & Day 20 & 31.3 & Contact tracing & No \\
\hline 110 & Male & $40-44$ & Day 0 & 68.6 & Day 55 & NR & Survey** & No \\
\hline 111 & Female & $30-34$ & Day 0 & 73.9 & Day 79 & NR & Survey ${ }^{* *}$ & No \\
\hline 112 & Male & $60-64$ & Day 0 & 76.5 & Day 59 & NR & Healthcare routine testing & No \\
\hline 113 & Female & $30-34$ & Day 0 & 77.3 & Day 32 & 37.1 & Contact tracing & No \\
\hline 114 & Male & $45-49$ & Day 0 & 81.5 & Day 39 & 34.6 & Healthcare routine testing & No \\
\hline 115 & Male & $65-69$ & Day 0 & 85.6 & Day 70 & 35.7 & Port of entry & No \\
\hline 116 & Male & $30-34$ & Day 0 & 92.2 & Day 139 & NR & Healthcare routine testing & No \\
\hline 117 & Male & $40-44$ & Day 0 & 94.1 & Day 18 & 38.3 & Survey $^{* *}$ & No \\
\hline 118 & Male & $30-34$ & Day 0 & 97.1 & Day 16 & 35.8 & Healthcare routine testing & No \\
\hline 119 & Male & $40-44$ & Day 0 & 101.0 & Day 96 & 33.1 & Clinical suspicion ${ }^{\S}$ & Yes \\
\hline 120 & Male & $40-44$ & Day 0 & 101.9 & Day 39 & 35.0 & Survey $^{* *}$ & No \\
\hline 121 & Male & $55-59$ & Day 0 & 105.3 & Day 47 & NR & Clinical suspicion $\S$ & $\mathrm{No}^{\dagger \dagger}$ \\
\hline 122 & Male & $35-39$ & Day 0 & 109.2 & Day 121 & NR & Survey $^{* *}$ & No \\
\hline 123 & Male & $30-34$ & Day 0 & 121.9 & Day 23 & 35.8 & Contact tracing & No \\
\hline 124 & Male & $35-39$ & Day 0 & 124.4 & Day 20 & NR & Individual request $^{\dagger}$ & No \\
\hline 125 & Male & $40-44$ & Day 0 & 125.3 & Day 44 & 35.8 & Clinical suspicion $\S$ & $\mathrm{No}^{\dagger \dagger}$ \\
\hline 126 & Female & $60-64$ & Day 0 & 128.0 & Day 21 & 34.2 & Survey ${ }^{* *}$ & No \\
\hline 127 & Male & $35-39$ & Day 0 & 141.0 & Day 15 & NR & Survey ${ }^{* *}$ & No \\
\hline 128 & Male & $35-39$ & Day 0 & 146.0 & Day 35 & NR & Clinical suspicion $\$$ & Yes \\
\hline 129 & Male & $30-34$ & Day 0 & 150.0 & Day 25 & 34.1 & Healthcare routine testing & No \\
\hline
\end{tabular}

Ab, antibody; Asymp, asymptomatic; Ct, cycle threshold; NR, not reported; PCR, polymerase chain reaction.

The table is sorted by antibody test optical density value (antibody titer).

The light blue color highlights reinfection cases that were confirmed by viral genome sequencing.

*Average PCR Ct value over different targets for SARS-CoV-2 genes and/or proteins.

†The category "individual request" refers to testing conducted at a healthcare facility based on the individual's request, often because of some requirement for testing, such as for travel.

ॠThe category "port of entry" refers to testing conducted at the border or airport upon return from travel.

${ }^{\S}$ The category "clinical suspicion" refers to testing conducted at a healthcare facility based on presence of signs or symptoms, or reported history of exposure.

** The category "survey" refers to surveillance random PCR testing campaigns conducted in workplaces and residential areas.

"The reason for the swab in the hospital record was "clinical suspicion", but no further details were provided and the person was reported to have no COVID-19 symptoms. 
Table 2. Results of reinfection confirmation using viral genome sequencing. Viral genome sequencing was conducted only for a subset of cases with good or some evidence of reinfection, that is, whenever paired samples of the first-infection PCR-positive swab and the reinfection PCR-positive swab were available.

\begin{tabular}{|c|c|c|}
\hline Viral genome sequencing evidence for reinfection & Indication upon comparing each genome pair & $\mathbf{N}$ \\
\hline Insufficient evidence to warrant interpretation & One or two genomes of low quality & 7 \\
\hline No evidence for reinfection & One change of allele frequency & 1 \\
\hline Shifting balance of quasi-species with no evidence for reinfection & $\begin{array}{l}\text { Few changes of allele frequency but not sufficiently indicative of } \\
\text { reinfection }\end{array}$ & 6 \\
\hline Strong evidence for no reinfection & Both genomes of high quality yet no significant differences found & $4^{*}$ \\
\hline Supporting evidence for reinfection & Few changes of allele frequency indicative of reinfection & 1 \\
\hline Strong evidence for reinfection & Multiple changes of allele frequency indicative of reinfection & 4 \\
\hline Total & & 23 \\
\hline
\end{tabular}

PCR, polymerase chain reaction.

*Viral genome sequencing for two patients was performed as part of an earlier study assessing the risk of SARS-CoV-2 reinfection in the cohort of PCR-confirmed infected persons in Qatar [5]. 
Figure 2. Viral genome sequencing analysis of paired viral specimens of the primary-infection PCR-positive swab and the reinfection PCR-positive swab for five cases with strong or supporting evidence of reinfection.

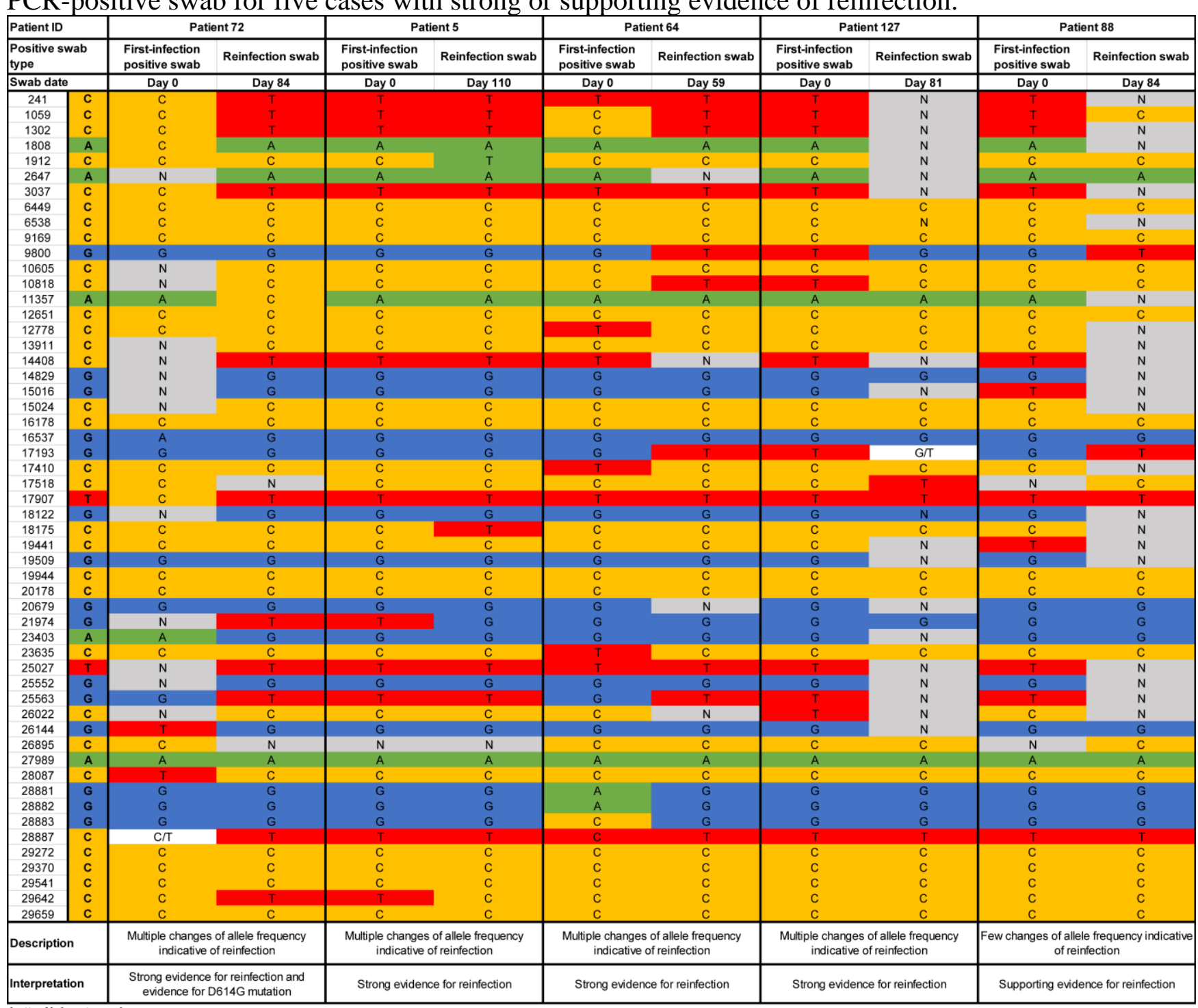

Letter $\mathrm{N}$ denotes unknown.

\begin{tabular}{|l|l|l}
\hline Strong evidence for reinfection & Strong evidence for reinfection \\
\hline
\end{tabular}

Numbers in cells represent the balance of reads for the reference and alternate alleles in that order. 
Figure 3. Incidence rate of documented SARS-CoV-2 reinfection versus month of follow-up in the cohort of 43,044 antibody-positive persons.

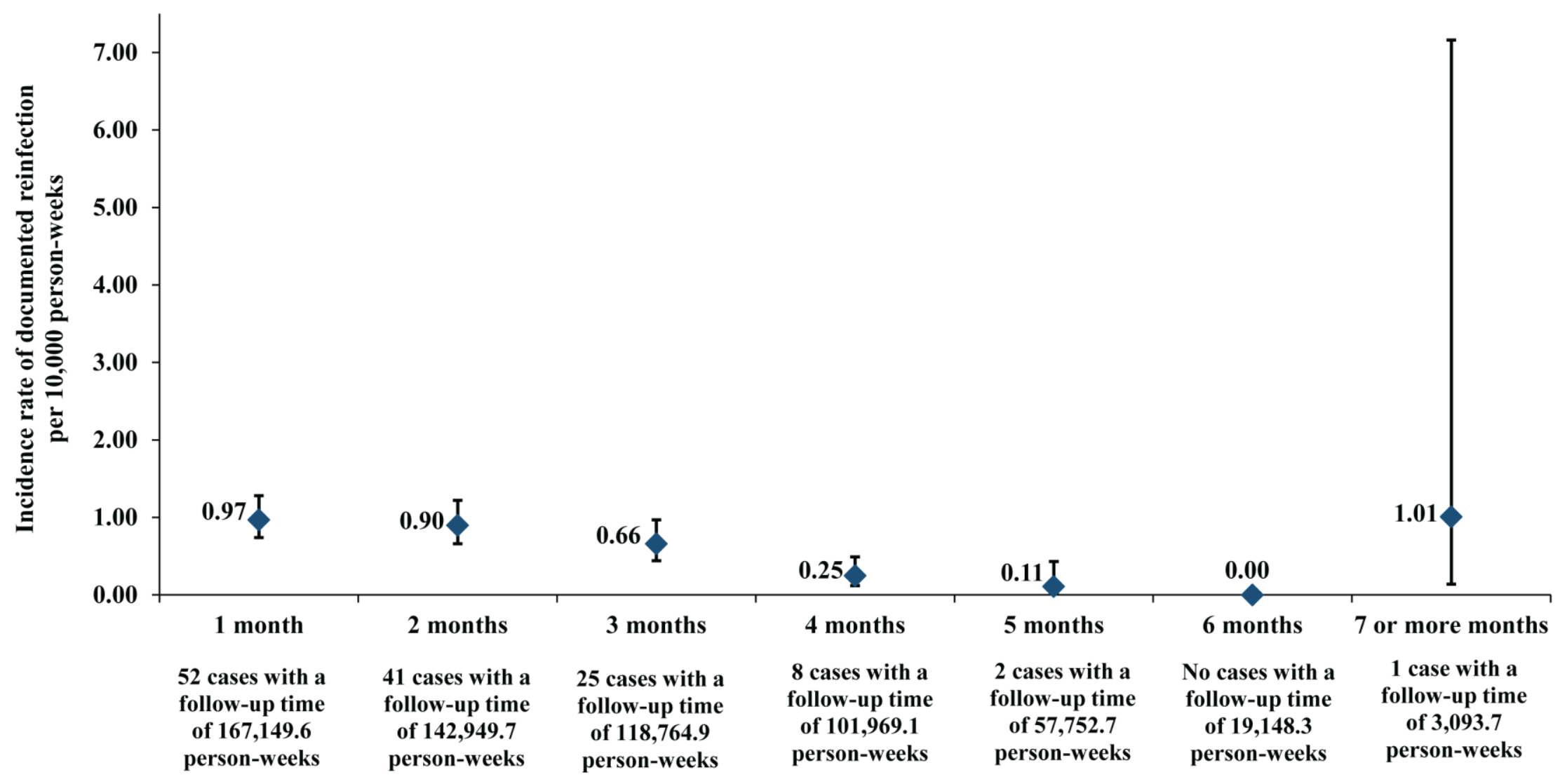

Time difference between the first antibody-positive test and the reinfection swab 
medRxiv preprint doi: https://doi.org/10.1101/2021.01.15.21249731; this version posted February 8, 2021. The copyright holder for this preprint (which was not certified by peer review) is the author/funder, who has granted medRxiv a license to display the preprint in perpetuity.

All rights reserved. No reuse allowed without permission.

Figure 4. Flow chart describing the process for identifying SARS-CoV-2 incident infections in the complement cohort of antibody-negative individuals.

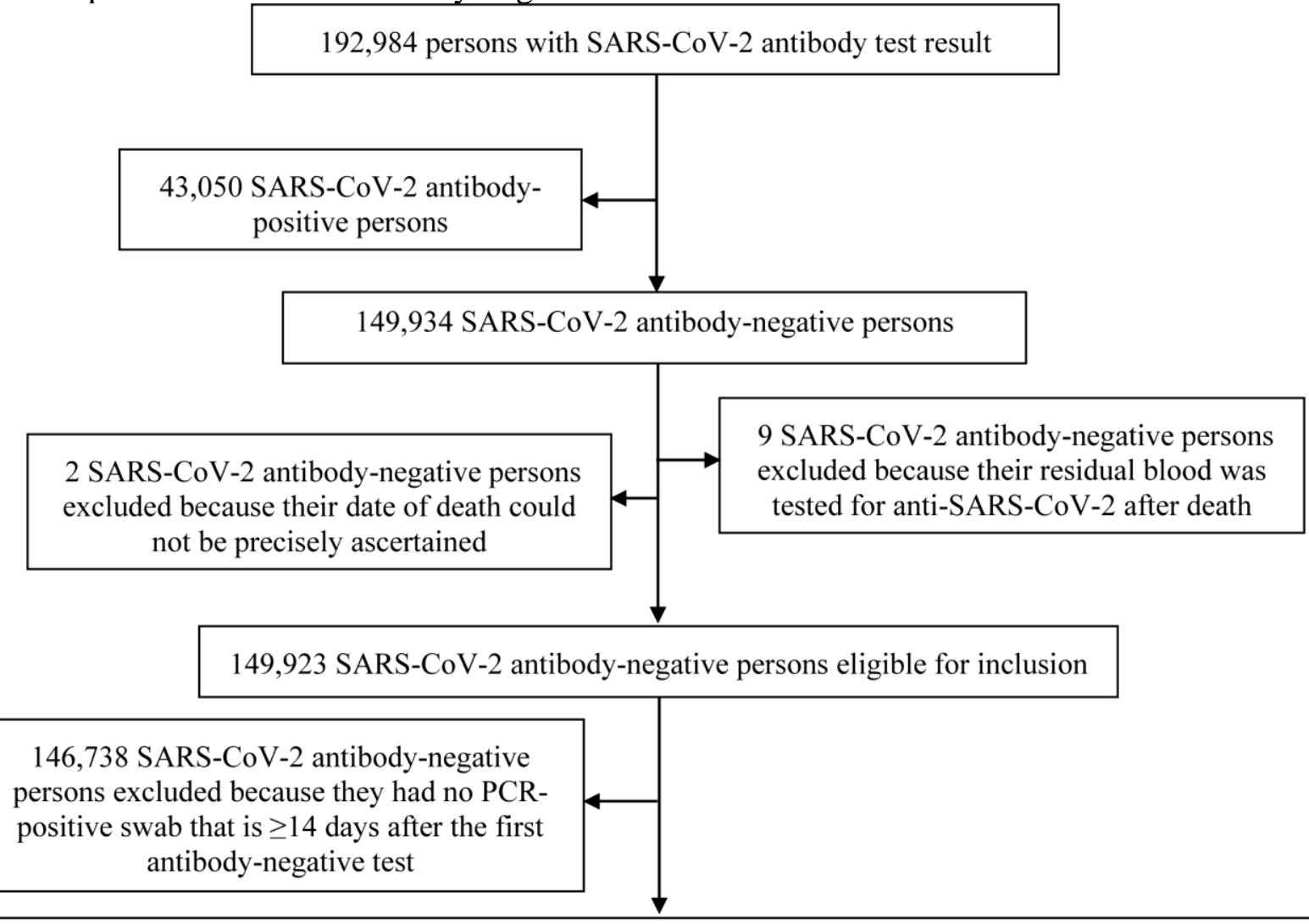

3,185 SARS-CoV-2 antibody-negative persons with at least one PCR-positive swab that is $\geq 14$ days after the first antibody-negative test

*PCR, polymerase chain reaction 
medRxiv preprint doi: https://doi.org/10.1101/2021.01.15.21249731; this version posted February 8, 2021. The copyright holder for this preprint (which was not certified by peer review) is the author/funder, who has granted medRxiv a license to display the preprint in perpetuity.

All rights reserved. No reuse allowed without permission.

\section{Supplementary Material}

\section{SARS-CoV-2 reinfection in a cohort of 43,000 antibody-}

\section{positive individuals followed for up to 35 weeks}


medRxiv preprint doi: https://doi.org/10.1101/2021.01.15.21249731; this version posted February 8, 2021. The copyright holder for this preprint (which was not certified by peer review) is the author/funder, who has granted medRxiv a license to display the preprint in perpetuity.

\section{Text S1. Details of the viral genome sequencing methods.}

Viral RNA was extracted using Quick-RNA Viral Kit (Zymo Research, Irvine, USA; Cat. No. R1041) and eluted in 30ul of nuclease-free water. RNA quality was assessed with real-time quantitative polymerase chain reaction (RT-qPCR) using SARS-CoV-2 (2019-nCoV) CDC qPCR Probe Assay Research Use Only (RUO) kit (Integrated DNA Technologies, USA; Cat number 10006713) and Luna Universal Probe One-Step RT-qPCR Kit (New England BioLabs, USA; Cat number E3006E) on Applied Biosystems 7500 Fast Real-Time PCR instrument (Applied Biosystems, CA, USA).

Next-generation sequencing (NGS) library construction was performed using CleanPlex SARSCoV-2 Panel (Paragon Genomics, USA; SKU: 918012). Gel-size selection on a 3\% agarose gel was utilized to prevent formation of adapter dimers. NGS libraries were quantified using KAPA Library Quantification Kit (Roche, USA; KK4824), and normalized, pooled, and sequenced on an Illumina MiSeq instrument using a paired-end 150bp kit (Illumina, USA; MS-102-2002). All procedures were implemented following manufacturers' protocols.

Raw sequences were processed with CUTADAPT (v2.10) [1] to exclude the contaminating adapter sequences. Adapter trimming was performed using parameters -g CCTACACGACGCTCTTCCGATCT -a AGATCGGAAGAGCACACGTCTGAA -A AGATCGGAAGAGCGTCGTGTAGG -G TTCAGACGTGTGCTCTTCCGATCT -e 0.1 -o 9 -m 50 -n 2. Only paired reads with minimum length of 50bp were retained for analysis. The latter filtered reads were aligned to SARS-CoV-2 reference genome (NC_045512) using BWAMEM [2]. FGBIO (v1.3.0) was subsequently used to remove PCR primer sequences from the resulting BAM file. 
medRxiv preprint doi: https://doi.org/10.1101/2021.01.15.21249731; this version posted February 8, 2021. The copyright holder for this preprint (which was not certified by peer review) is the author/funder, who has granted medRxiv a license to display the preprint in perpetuity. All rights reserved. No reuse allowed without permission.

Variant calling and genotyping were performed with VarScan multi-sample mpileup [3] with the pileup file generated using SAMTOOLS mpileup (v1.10) [4] with --min-BQ 20 and --min-MQ 20 parameters. The mpileup2snp function of VarScan was then applied with the filtering parameters --min-var-freq 0.2 , --min-coverage 5, and --min-avg-qual 20, to generate the final VCF file. 
Figure S1. Viral genome sequencing analysis of the paired viral specimens of the primary-infection PCR-positive swab and the reinfection PCR-positive swab for the eleven cases with evidence not supporting occurrence of reinfection.

A) Two individuals with strong evidence for no reinfection (using viral genome sequencing conducted in this study)

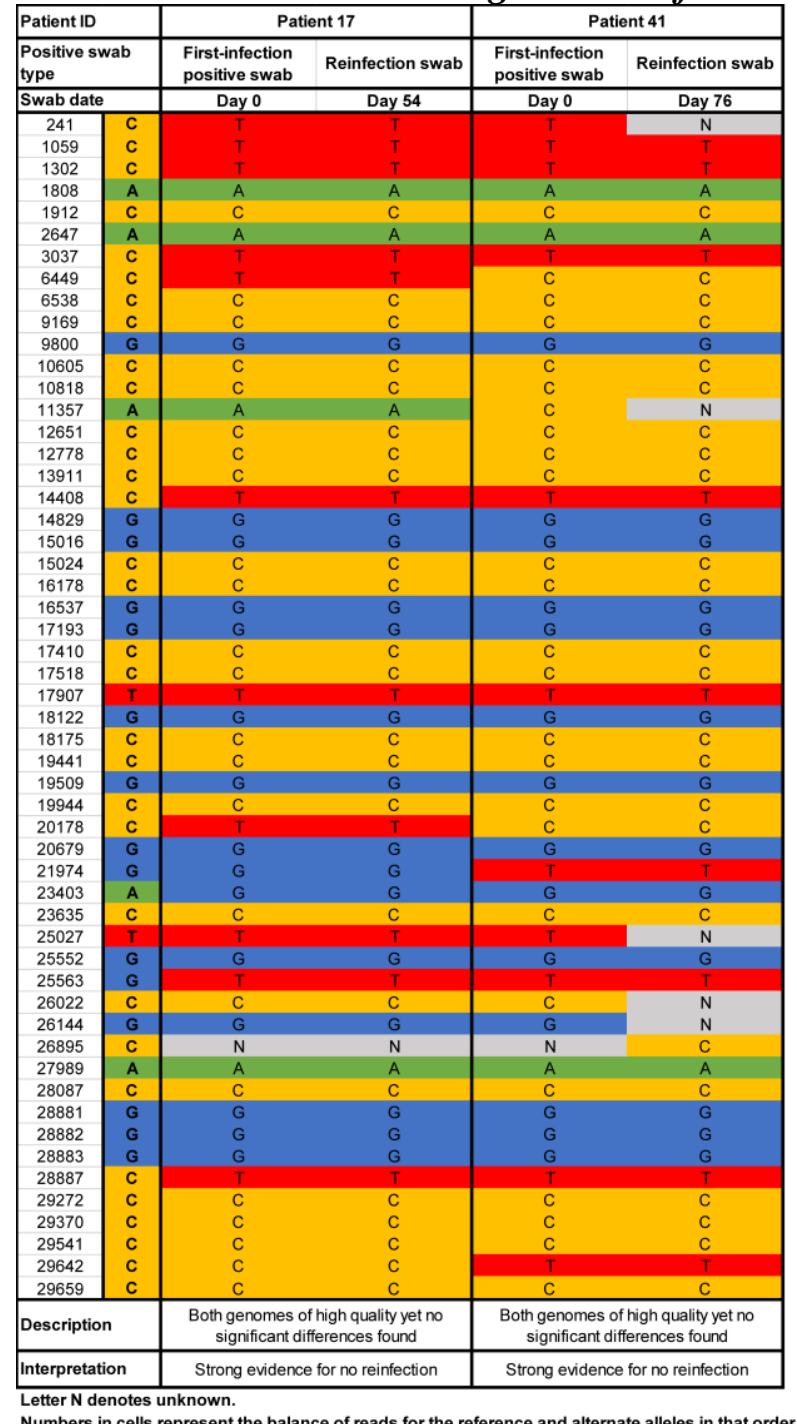

alternate alleles in that order.

Manual calls are represented by white cells with the nucleotide call. 
B) Two individuals with strong evidence for no reinfection (using viral genome sequencing conducted in an earlier study [5])

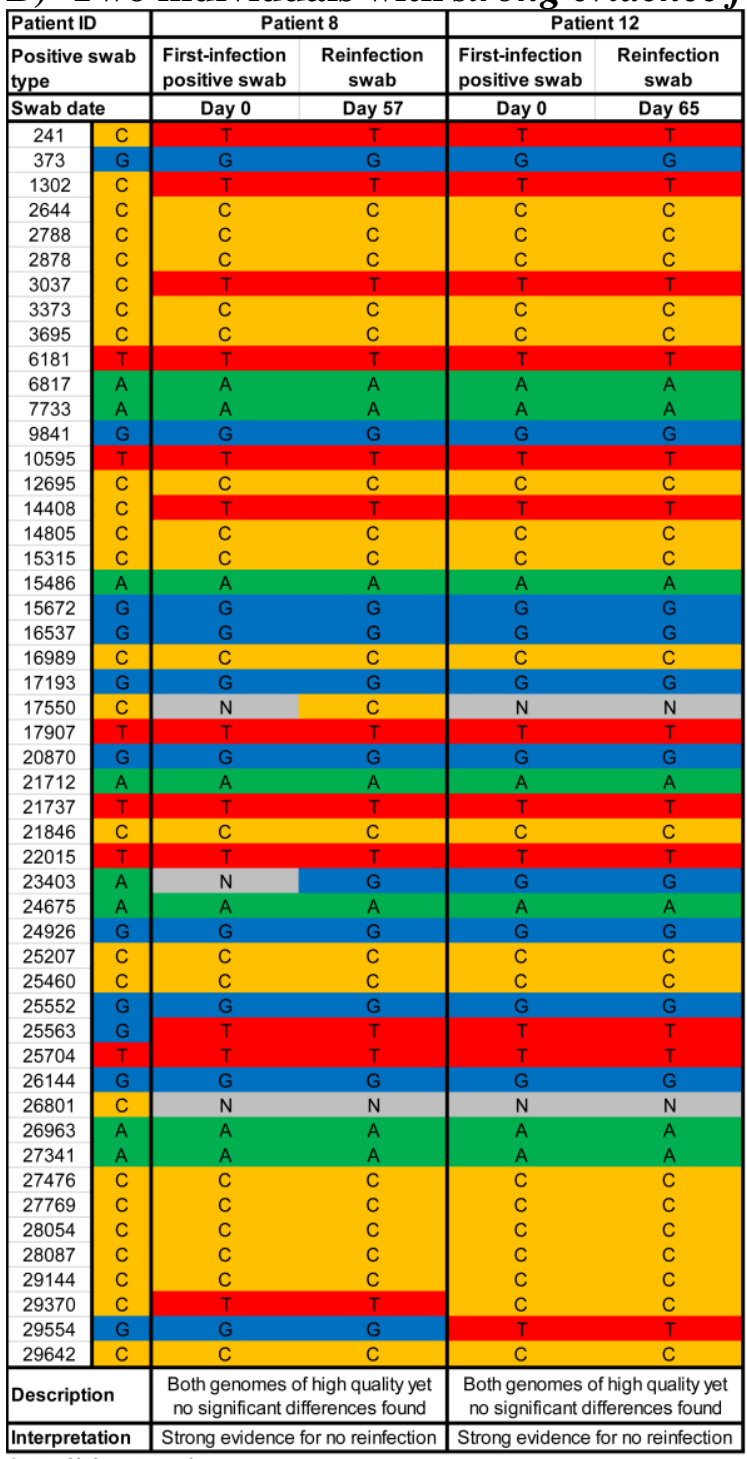

\begin{tabular}{|c|c|c|c|} 
& no significant differences found & no significant differences found \\
\hline interpretation & Strong evidence for no reinfection & Strong evidence for no reinfection \\
\hline
\end{tabular}

Numbers in cells represent the balance of reads for the reference and at Manual calls are represented by white cells with the nucleotide call. 
C) Seven individuals with no evidence for reinfection

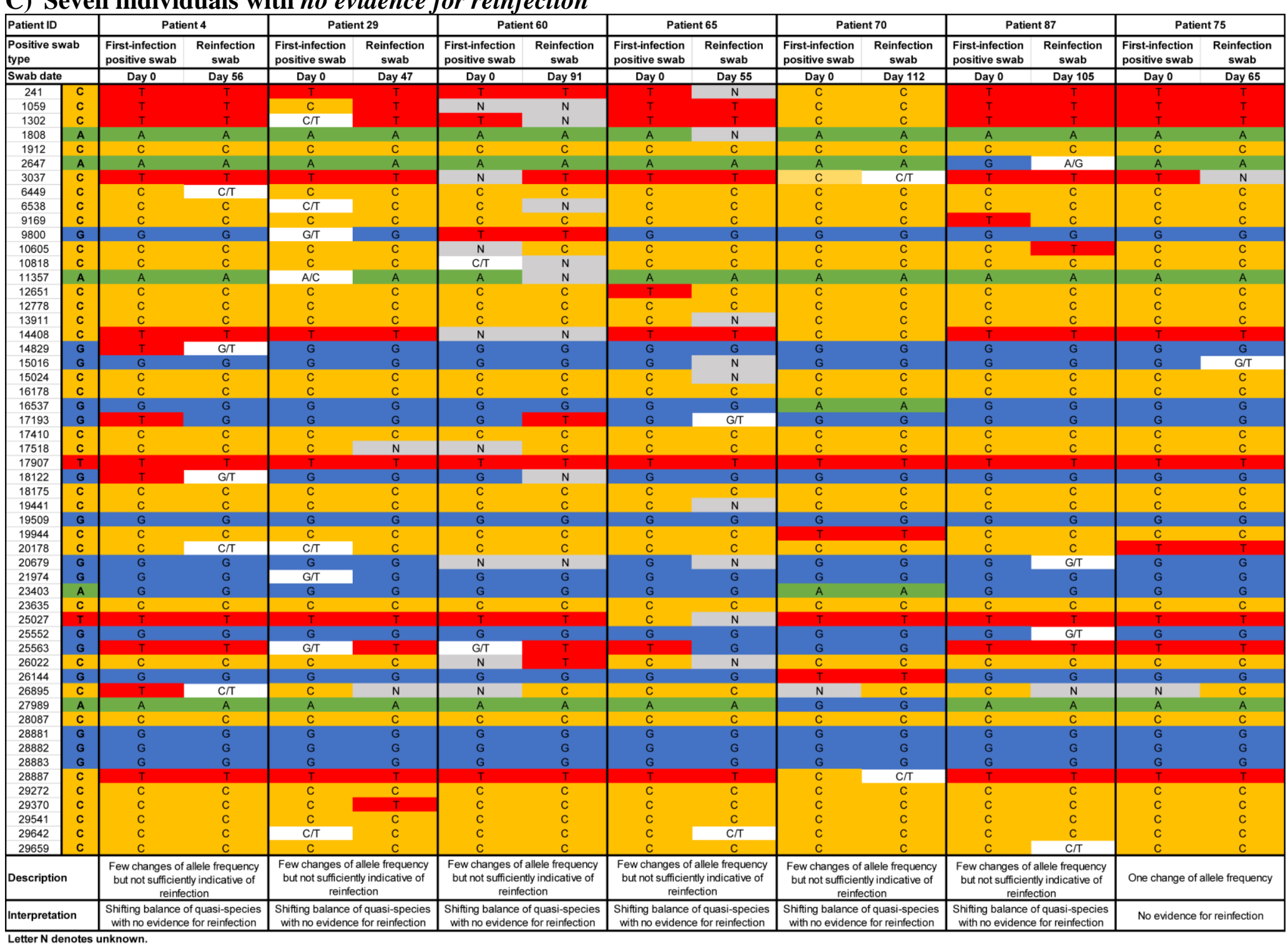

Letter $\mathrm{N}$ denotes unknown

Numbers in cells represent the balance of reads for the reference and alternate alleles in that order.
Manual calls are represented by white cells with the nucleotide call. 
Figure S2. Viral genome sequencing analysis of the paired viral specimens of the primary-infection PCR-positive swab and the reinfection PCR-positive swab for the seven cases with insufficient genetic evidence to confirm the reinfection.

\begin{tabular}{|c|c|c|c|c|c|c|c|c|c|c|c|c|c|c|c|}
\hline \multicolumn{2}{|c|}{\begin{tabular}{|l|} 
Patient ID \\
Positive swab \\
\end{tabular}} & \multicolumn{2}{|c|}{ Patient 19} & \multicolumn{2}{|c|}{ Patient 34} & \multicolumn{2}{|c|}{ Patient 39} & \multicolumn{2}{|c|}{ Patient 46} & \multicolumn{2}{|c|}{ Patient 86} & \multicolumn{2}{|c|}{ Patient 101} & \multicolumn{2}{|c|}{ Patient 124} \\
\hline \multirow{2}{*}{\multicolumn{2}{|c|}{$\begin{array}{l}\text { Type } \\
\text { Swab date }\end{array}$}} & $\begin{array}{l}\text { First-infection } \\
\text { positive swab }\end{array}$ & $\begin{array}{l}\text { Reinfection } \\
\text { swab }\end{array}$ & \begin{tabular}{|l|} 
First-infection \\
positive swab
\end{tabular} & $\begin{array}{c}\text { Reinfection } \\
\text { swab }\end{array}$ & \begin{tabular}{|l} 
First-infection \\
positive swab
\end{tabular} & $\begin{array}{c}\text { Reinfection } \\
\text { swab }\end{array}$ & \begin{tabular}{|l|} 
First-infection \\
positive swab
\end{tabular} & $\begin{array}{l}\text { Reinfection } \\
\text { swab }\end{array}$ & $\begin{array}{l}\text { First-infection } \\
\text { positive swab }\end{array}$ & $\begin{array}{l}\text { Reinfection } \\
\text { swab }\end{array}$ & \begin{tabular}{|l|} 
First-infection \\
positive swab
\end{tabular} & $\begin{array}{c}\text { Reinfection } \\
\text { swab }\end{array}$ & $\begin{array}{l}\text { First-infection } \\
\text { positive swab }\end{array}$ & $\begin{array}{l}\text { Reinfection } \\
\text { swab }\end{array}$ \\
\hline & & Day 0 & $\begin{array}{l}\text { Day } 137 \\
\end{array}$ & Day 0 & Day 54 & Day 0 & Day 49 & Day 0 & Day 80 & \begin{tabular}{|l} 
Day 0 \\
\end{tabular} & Day 57 & \begin{tabular}{|l|} 
Day 0 \\
\end{tabular} & Day 87 & Day 0 & $\begin{array}{l}\text { Day } 87 \\
\end{array}$ \\
\hline & C & & $\mathrm{N}$ & $\mathrm{N}$ & $\mathrm{N}$ & & $\mathrm{N}$ & & $\mathrm{N}$ & & $\mathrm{N}$ & & $\mathrm{N}$ & $\mathrm{N}$ & $\mathrm{N}$ \\
\hline 1059 & c & $T$ & $\mathrm{~N}$ & c & $\mathrm{N}$ & $\mathrm{C} / \mathrm{T}$ & c & T & $\mathrm{N}$ & $\mathrm{C} / \mathrm{T}$ & $\mathrm{N}$ & c & $\mathrm{N}$ & $\mathrm{N}$ & $\mathrm{N}$ \\
\hline 1302 & c & $T$ & $\mathrm{~N}$ & $\mathrm{~N}$ & $\mathrm{~N}$ & $\mathrm{C} \pi$ & $\mathrm{N}$ & $T$ & $\mathrm{~N}$ & & $\mathrm{~N}$ & c & $\mathrm{N}$ & $\mathrm{N}$ & $\mathrm{N}$ \\
\hline 1808 & A & A & $\mathrm{N}$ & $\mathrm{N}$ & $\mathrm{N}$ & A & $\mathrm{N}$ & A & $\mathrm{N}$ & A & $\mathrm{N}$ & A & $\mathrm{N}$ & $\mathrm{N}$ & $\mathrm{N}$ \\
\hline 1912 & c & c & $\mathrm{N}$ & $\mathrm{N}$ & $\mathrm{N}$ & c & $\mathrm{N}$ & c & $\mathrm{N}$ & c & $\mathrm{N}$ & c & $\mathrm{N}$ & $\mathrm{N}$ & $\mathrm{N}$ \\
\hline 2647 & A & A & $\mathrm{N}$ & $\mathrm{N}$ & $\mathrm{N}$ & A & $\mathrm{N}$ & A & $\mathrm{N}$ & A & $\mathrm{N}$ & A & $\mathrm{N}$ & $\mathrm{N}$ & A \\
\hline 3037 & c & $T$ & $\mathrm{~N}$ & $\mathrm{~N}$ & $\mathrm{~N}$ & $T$ & c & $T$ & $\mathrm{~N}$ & c & $\mathrm{N}$ & $T$ & $\mathrm{~N}$ & $\mathrm{~N}$ & $\mathrm{~N}$ \\
\hline 6449 & c & c & $\mathrm{N}$ & $\mathrm{N}$ & $\mathrm{N}$ & C & $\mathrm{N}$ & C & $\mathrm{N}$ & c & $\mathrm{N}$ & C & $\mathrm{N}$ & $\mathrm{N}$ & $\mathrm{N}$ \\
\hline 6538 & c & c & $\mathrm{N}$ & $\mathrm{N}$ & $\mathrm{N}$ & c & $\mathrm{N}$ & c & $\mathrm{N}$ & c & $\mathrm{N}$ & & $\mathrm{N}$ & $\mathrm{N}$ & $\mathrm{N}$ \\
\hline 9169 & c & c & $\mathrm{N}$ & $\mathrm{N}$ & $\mathrm{N}$ & c & $\mathrm{N}$ & c & $\mathrm{N}$ & c & $\mathrm{N}$ & c & $\mathrm{N}$ & $\mathrm{N}$ & c \\
\hline 9800 & G & G & $\mathrm{N}$ & $\mathrm{N}$ & $\mathrm{N}$ & G & $\mathrm{N}$ & G & $\mathrm{N}$ & $\mathrm{T}$ & $\mathrm{N}$ & G & $\mathrm{N}$ & $\mathrm{N}$ & G \\
\hline 10605 & c & $T$ & $\mathrm{~N}$ & c & $\mathrm{N}$ & C & $\mathrm{N}$ & c & $\mathrm{N}$ & $\mathrm{N}$ & $\mathrm{N}$ & c & $\mathrm{N}$ & $\mathrm{N}$ & c \\
\hline 10818 & c & C & $\mathrm{N}$ & c & $\mathrm{N}$ & c & $\mathrm{N}$ & c & $\mathrm{N}$ & $\mathrm{C} / \mathrm{T}$ & $\mathrm{N}$ & c & C & $\mathrm{N}$ & C \\
\hline 11357 & A & A & $\mathrm{N}$ & $\mathrm{N}$ & $\mathrm{N}$ & A & $\mathrm{N}$ & A & $\mathrm{N}$ & A & $\mathrm{N}$ & A & $\mathrm{N}$ & $\mathrm{N}$ & c \\
\hline 12651 & c & C & $\mathrm{N}$ & C & $\mathrm{N}$ & C & $\mathrm{N}$ & C & $\mathrm{N}$ & C & $\mathrm{N}$ & C & $\mathrm{N}$ & $\mathrm{N}$ & C \\
\hline 12778 & c & C & $\mathrm{N}$ & C & $\mathrm{N}$ & C & $\mathrm{N}$ & C & $\mathrm{N}$ & C & $\mathrm{N}$ & C & $\mathrm{N}$ & $\mathrm{N}$ & C \\
\hline 13911 & c & C & $\mathrm{N}$ & $\mathrm{N}$ & $\mathrm{N}$ & C & $\mathrm{N}$ & C & $\mathrm{N}$ & C & $\mathrm{N}$ & C & $\mathrm{N}$ & $\mathrm{N}$ & $\mathrm{N}$ \\
\hline 14408 & c & $T$ & $\mathrm{~N}$ & $\mathrm{~N}$ & $\mathrm{~N}$ & $T$ & $\mathrm{~N}$ & $T$ & $\mathrm{~N}$ & $\mathrm{~N}$ & $\mathrm{~N}$ & $T$ & $\mathrm{~N}$ & $\mathrm{~N}$ & $\mathrm{~N}$ \\
\hline 14829 & G & G & $\mathrm{N}$ & $\mathrm{N}$ & $\mathrm{N}$ & $\mathrm{G} / \mathrm{T}$ & $\mathrm{N}$ & G & $\mathrm{N}$ & G & $\mathrm{N}$ & G & $\mathrm{N}$ & $\mathrm{N}$ & G \\
\hline 15016 & G & G & $\mathrm{N}$ & $\mathrm{N}$ & $\mathrm{N}$ & G & $\mathrm{N}$ & G & $\mathrm{N}$ & G & $\mathrm{N}$ & G & $\mathrm{N}$ & $\mathrm{N}$ & G \\
\hline 15024 & c & C & $\mathrm{N}$ & $\mathrm{N}$ & $\mathrm{N}$ & $T$ & $\mathrm{~N}$ & C & $\mathrm{N}$ & C & $\mathrm{N}$ & C & $\mathrm{N}$ & $\mathrm{N}$ & C \\
\hline 16178 & c & C & $\mathrm{N}$ & $\mathrm{N}$ & $\mathrm{N}$ & C & $\mathrm{N}$ & C & C & c & $\mathrm{N}$ & C & $\mathrm{N}$ & $\mathrm{N}$ & $\mathrm{N}$ \\
\hline 16537 & $G$ & G & $\mathrm{N}$ & $\mathrm{N}$ & $\mathrm{N}$ & G & $\mathrm{N}$ & G & G & G & $\mathrm{N}$ & G & $\mathrm{N}$ & $\mathrm{N}$ & $\mathrm{G} / \mathrm{A}$ \\
\hline 17193 & G & G & $\mathrm{N}$ & $\mathrm{N}$ & $\mathrm{N}$ & $\mathrm{G} / \mathrm{T}$ & G & G & G & $\mathrm{G} / \mathrm{T}$ & $\mathrm{N}$ & G & $\mathrm{N}$ & $\mathrm{N}$ & G \\
\hline 17410 & C & C & $\mathrm{N}$ & $\mathrm{N}$ & $\mathrm{N}$ & C & $\mathrm{N}$ & C & C & C & $\mathrm{N}$ & C & $\mathrm{N}$ & $\mathrm{N}$ & C \\
\hline 17518 & c & C & $\mathrm{N}$ & $\mathrm{N}$ & $\mathrm{N}$ & $\mathrm{N}$ & $\mathrm{N}$ & $\mathrm{N}$ & C & C & $\mathrm{N}$ & C & $\mathrm{N}$ & $\mathrm{N}$ & $\mathrm{N}$ \\
\hline 17907 & $T$ & $T$ & $\mathrm{~N}$ & $\mathrm{~N}$ & $\mathrm{~N}$ & $\mathrm{~T}$ & $\mathrm{~N}$ & $T$ & $T$ & $T$ & $\mathrm{~N}$ & $T$ & $\mathrm{~N}$ & $\mathrm{~N}$ & $T$ \\
\hline 18122 & G & G & $\mathrm{N}$ & $\mathrm{N}$ & $\mathrm{N}$ & $\mathrm{G} / T$ & $\mathrm{~N}$ & G & $\mathrm{N}$ & G & $\mathrm{N}$ & G & $\mathrm{N}$ & $\mathrm{N}$ & G \\
\hline 18175 & c & c & $\mathrm{N}$ & $\mathrm{N}$ & $\mathrm{N}$ & C & $\mathrm{N}$ & C & $\mathrm{N}$ & $\mathrm{N}$ & $\mathrm{N}$ & c & $\mathrm{N}$ & $\mathrm{N}$ & $\mathrm{N}$ \\
\hline 19441 & c & C & $\mathrm{N}$ & $\mathrm{N}$ & $\mathrm{N}$ & C & $\mathrm{N}$ & C & $\mathrm{N}$ & C & $\mathrm{N}$ & C & $\mathrm{N}$ & $\mathrm{N}$ & C \\
\hline 19509 & G & G & $\mathrm{N}$ & $\mathrm{N}$ & $\mathrm{N}$ & A & $\mathrm{N}$ & G & $\mathrm{N}$ & G & $\mathrm{N}$ & G & $\mathrm{N}$ & $\mathrm{N}$ & G \\
\hline 19944 & c & c & $\mathrm{N}$ & $\mathrm{N}$ & $\mathrm{N}$ & c & $\mathrm{N}$ & C & $\mathrm{N}$ & c & $\mathrm{N}$ & c & $\mathrm{N}$ & $\mathrm{N}$ & c \\
\hline 20178 & c & C & $\mathrm{N}$ & $\mathrm{N}$ & $\mathrm{N}$ & C & $\mathrm{N}$ & C & c & C & $\mathrm{N}$ & C & $\mathrm{N}$ & $\mathrm{N}$ & C \\
\hline 20679 & G & T & $\mathrm{N}$ & $\mathrm{N}$ & $\mathrm{N}$ & G & $\mathrm{N}$ & G & $\mathrm{N}$ & $\mathrm{N}$ & $\mathrm{N}$ & G & $\mathrm{N}$ & $\mathrm{N}$ & $\begin{array}{c}G \\
T\end{array}$ \\
\hline 21974 & G & G & $\mathrm{N}$ & $\mathrm{N}$ & $\mathrm{N}$ & G & $\mathrm{N}$ & G & $\mathrm{N}$ & G & $\mathrm{N}$ & G & $\mathrm{N}$ & $\mathrm{N}$ & $T$ \\
\hline $\begin{array}{r}23403 \\
2363\end{array}$ & A & G & $\mathrm{N}$ & $\mathrm{N}$ & $\mathrm{N}$ & G & $\mathrm{N}$ & G & $\mathrm{N}$ & G & $\mathrm{N}$ & G & $\mathrm{N}$ & $\mathrm{N}$ & $\mathrm{N}$ \\
\hline $\begin{array}{r}23635 \\
25027\end{array}$ & $\begin{array}{l}\text { C } \\
\text { T }\end{array}$ & $\begin{array}{l}C \\
T\end{array}$ & $\mathrm{~N}$ & $\mathrm{~N}$ & $\mathrm{~N}$ & $\begin{array}{l}C \\
\end{array}$ & $\mathrm{~N}$ & $\begin{array}{c}\text { C } \\
T\end{array}$ & $\mathrm{~N}$ & C & $\mathrm{N}$ & C & $\mathrm{N}$ & $\mathrm{N}$ & C \\
\hline $\begin{array}{l}25027 \\
25552\end{array}$ & $\begin{array}{l}T \\
G\end{array}$ & $\begin{array}{l}T \\
T\end{array}$ & $\begin{array}{l}\mathrm{N} \\
\mathrm{N}\end{array}$ & $\begin{array}{l}\mathrm{N} \\
\mathrm{N}\end{array}$ & $\begin{array}{l}\mathrm{N} \\
\mathrm{N}\end{array}$ & $\begin{array}{l}T \\
G\end{array}$ & $\begin{array}{l}\mathrm{N} \\
\mathrm{N}\end{array}$ & $\begin{array}{l}T \\
G\end{array}$ & $\begin{array}{l}\mathrm{N} \\
\mathrm{N}\end{array}$ & $\begin{array}{l}\mathrm{N} \\
\mathrm{G}\end{array}$ & $\begin{array}{l}\mathrm{N} \\
\mathrm{N}\end{array}$ & $\begin{array}{l}T \\
G\end{array}$ & $\begin{array}{l}\mathrm{N} \\
\mathrm{N}\end{array}$ & $\begin{array}{l}\mathrm{N} \\
\mathrm{N}\end{array}$ & $\begin{array}{l}T \\
G\end{array}$ \\
\hline 25563 & $G$ & $T$ & $\mathrm{~N}$ & $\mathrm{~N}$ & $\mathrm{~N}$ & $G$ & $\mathrm{~N}$ & $T$ & $\mathrm{~N}$ & $T$ & $\mathrm{~N}$ & G & $\mathrm{N}$ & $\mathrm{N}$ & $G$ \\
\hline 26022 & c & C & $\mathrm{N}$ & $c$ & $\mathrm{~N}$ & $c$ & $\mathrm{~N}$ & C & $\mathrm{N}$ & $\mathrm{N}$ & $\mathrm{N}$ & c & $\mathrm{N}$ & $\mathrm{N}$ & $\mathrm{c}$ \\
\hline 26144 & G & G & $\mathrm{N}$ & $\mathrm{N}$ & $\mathrm{N}$ & G & $\mathrm{N}$ & G & $\mathrm{N}$ & G & $\mathrm{N}$ & G & $\mathrm{N}$ & $\mathrm{N}$ & $\mathrm{N}$ \\
\hline 26895 & c & $\mathrm{N}$ & $\mathrm{N}$ & $\mathrm{N}$ & $\mathrm{N}$ & $\mathrm{N}$ & $\mathrm{N}$ & $\mathrm{N}$ & $\mathrm{N}$ & C & $\mathrm{N}$ & $\mathrm{N}$ & $\mathrm{N}$ & $\mathrm{N}$ & c \\
\hline 27989 & A & A & $\mathrm{N}$ & $\mathrm{N}$ & $\mathrm{N}$ & $A$ & $\mathrm{~N}$ & A & A & A & $\mathrm{N}$ & A & $\mathrm{N}$ & $\mathrm{N}$ & $\mathrm{N}$ \\
\hline 28087 & c & c & $\mathrm{N}$ & $\mathrm{N}$ & $\mathrm{N}$ & c & $\mathrm{N}$ & c & $\mathrm{N}$ & c & $\mathrm{N}$ & C & $\mathrm{N}$ & $\mathrm{N}$ & c \\
\hline 28881 & G & G & $\mathrm{N}$ & $\mathrm{N}$ & $\mathrm{N}$ & $\mathrm{G} / \mathrm{A}$ & $\mathrm{N}$ & $G$ & $G$ & G & $\mathrm{N}$ & G & $\mathrm{N}$ & $\mathrm{N}$ & G \\
\hline 28882 & G & G & $\mathrm{N}$ & $\mathrm{N}$ & $\mathrm{N}$ & $G / A$ & $\mathrm{~N}$ & G & G & G & $\mathrm{N}$ & G & $\mathrm{N}$ & $\mathrm{N}$ & G \\
\hline 28883 & $G$ & G & $\mathrm{N}$ & $\mathrm{N}$ & $\mathrm{N}$ & $\mathrm{G} / \mathrm{C}$ & $\mathrm{N}$ & G & G & G & $\mathrm{N}$ & G & $\mathrm{N}$ & $\mathrm{N}$ & G \\
\hline 28887 & c & $\mathrm{T}$ & $\mathrm{N}$ & $\mathrm{N}$ & $\mathrm{N}$ & $\mathrm{C} / \mathrm{T}$ & c & $\mathrm{T}$ & $\mathrm{C} / \mathrm{T}$ & $\mathrm{T}$ & $\mathrm{N}$ & c & $\mathrm{N}$ & $\mathrm{N}$ & $\mathrm{T}$ \\
\hline 29272 & c & c & $\mathrm{N}$ & $\mathrm{N}$ & $\mathrm{N}$ & $\mathrm{c}$ & $\mathrm{N}$ & $\mathrm{c}$ & c & $\mathrm{c}$ & $\mathrm{N}$ & $\mathrm{c}$ & $\mathrm{N}$ & $\mathrm{N}$ & $\mathrm{c}$ \\
\hline 29370 & c & c & $\mathrm{N}$ & c & $\mathrm{N}$ & c & $\mathrm{N}$ & c & $\mathrm{c}$ & c & $\mathrm{N}$ & $\mathrm{c}$ & $\mathrm{N}$ & $\mathrm{N}$ & $\mathrm{c}$ \\
\hline 29541 & c & c & $\mathrm{N}$ & $\mathrm{N}$ & $\mathrm{N}$ & c & $\mathrm{N}$ & c & $\mathrm{N}$ & c & $\mathrm{N}$ & c & $\mathrm{N}$ & $\mathrm{N}$ & $\mathrm{N}$ \\
\hline 29642 & c & c & $\mathrm{N}$ & $\mathrm{N}$ & $\mathrm{N}$ & c & $\mathrm{N}$ & c & $\mathrm{N}$ & c & c & c & $\mathrm{N}$ & $\mathrm{N}$ & $\mathrm{c}$ \\
\hline 29659 & c & $T$ & $\mathrm{~N}$ & $\mathrm{~N}$ & $\mathrm{~N}$ & c & $\mathrm{N}$ & c & $\mathrm{N}$ & c & $\mathrm{N}$ & c & $\mathrm{N}$ & $\mathrm{N}$ & c \\
\hline \multicolumn{2}{|c|}{ Description } & \multicolumn{2}{|c|}{ One or two genomes of low quality } & \multicolumn{2}{|c|}{ One or two genomes of low quality } & One or two genor & es of low quality & One or two genon & es of low quality & One or two genor & es of low quality & One or two geno & es of low quality & One or two geno & es of low quality \\
\hline Interpret & & $\begin{array}{l}\text { Insufficient evic } \\
\text { interp }\end{array}$ & $\begin{array}{l}\text { nce to warrant } \\
\text { gation }\end{array}$ & $\begin{array}{l}\text { Insufficient evid } \\
\text { interpre }\end{array}$ & $\begin{array}{l}\text { nce to warrant } \\
\text { tation }\end{array}$ & $\begin{array}{l}\text { Insufficient evid } \\
\text { interpr }\end{array}$ & $\begin{array}{l}\text { nce to warrant } \\
\text { tation }\end{array}$ & $\begin{array}{l}\text { Insufficient evid } \\
\text { interpr }\end{array}$ & $\begin{array}{l}\text { nce to warrant } \\
\text { ation }\end{array}$ & $\begin{array}{l}\text { Insufficient evid } \\
\text { interpr }\end{array}$ & $\begin{array}{l}\text { nce to warrant } \\
\text { ation }\end{array}$ & $\begin{array}{l}\text { Insufficient evic } \\
\text { interp }\end{array}$ & $\begin{array}{l}\text { nce to warrant } \\
\text { ation }\end{array}$ & $\begin{array}{l}\text { Insufficient evic } \\
\text { interpr }\end{array}$ & $\begin{array}{l}\text { nce to warrant } \\
\text { tation }\end{array}$ \\
\hline
\end{tabular}

Numbers in cells represent the balance of reads for the reference and alternate alleles in that order.

Manual calls are represented by white cells with the nucleotide call. 
medRxiv preprint doi: https://doi.org/10.1101/2021.01.15.21249731; this version posted February 8, 2021. The copyright holder for this preprint (which was not certified by peer review) is the author/funder, who has granted medRxiv a license to display the preprint in perpetuity. All rights reserved. No reuse allowed without permission.

\section{References}

1. Martin M., Cutadapt removes adapter sequences from high-throughput sequencing reads. ISSN 2226-6089. Available at:

<http://journal.embnet.org/index.php/embnetjournal/article/view/200>. Date accessed: 17 sep. 2020. doi:https://doi.org/10.14806/ej.17.1.200. EMBnet.journal, 2011. 17(1): p. 10-12.

2. $\mathrm{Li}, \mathrm{H}$. and R. Durbin, Fast and accurate short read alignment with Burrows-Wheeler transform. Bioinformatics, 2009. 25(14): p. 1754-60.

3. Koboldt, D.C., et al., VarScan: variant detection in massively parallel sequencing of individual and pooled samples. Bioinformatics, 2009. 25(17): p. 2283-5.

4. Li, H., et al., The Sequence Alignment/Map format and SAMtools. Bioinformatics, 2009. 25(16): p. 2078-9.

5. Abu-Raddad, L.J., et al., Assessment of the risk of SARS-CoV-2 reinfection in an intense reexposure setting. Clinical Infectious Diseases, 2020. ciaa1846. doi: 10.1093/cid/ciaa1846. . 